\title{
The Economic Potential of an India-US Free Trade Agreement
}

\author{
Emiko Fukase \\ World Bank, Washington DC, United States \\ Will Martin \\ International Food Policy Research Institute, Washington DC, United States
}

\begin{abstract}
This paper explores the economic implication of a potential free trade agreement between India and the United States. The overall impacts are likely to be positive for the United States and India. While gains from trade creation would be offset by trade diversion on the import side, both countries would gain from improved access on the export side. The United States is likely to gain largely through terms of trade improvements for its goods and services, as initial protection in India remains relatively high. India would experience an expansion of exports and output, particularly in textiles and apparel. The paper explores how the effects of an India-United States free trade agreement might be affected by prior free trade agreements. Adding an India-United States free trade agreement to prior agreements would tend to bring additional welfare benefits to both countries. India would also gain substantially if it concluded a free trade agreement with the United States and then extended it to other partners. The results suggest that an IndiaUnited States free trade agreement might become a building block toward more liberal trade regimes.
\end{abstract}

\footnotetext{
* Corresponding Author: Will Martin; International Food Policy Research Institute, 2033 K St NW, Washington DC, USA, Tel: +1 202 862 5628. E-mail: w.martin@cgiar.org.

Co-author: Emiko Fukase; World Bank, 1818 H Street, NW, Washington DC, 20433, USA, Tel:+1 917-873-4053,

E-mail: efukase@worldbank.org, emikof2@aol.com.
} 
Keywords: Free Trade Agreement, India, United States, CGE

JEL Classification: F13, F15, F17

\section{Introduction}

As Lawrence and Chadha (2004) noted more than a decade ago, now may not appear to be the time for a Free Trade Area (FTA) between India and the United States (US). But much has changed since Lawrence and Chadha examined the issue. In particular, India has substantially liberalized its trade and investment regime, and now appears poised to be a strong engine of growth in an otherwise faltering world economy (International Monetary Fund (IMF) 2016). If this growth continues, the US may wish to improve its access to this large and fast-growing market. Further, if the proposed megaregional negotiations under the Trans-Pacific Partnership (TPP) and the Transatlantic Trade and Investment Partnership (TTIP) come to fruition, Indian policymakers may seek ways to unwind the resulting trade diversion. An India-US FTA remains among the options of both countries (Bergsten 2015) and the underlying economic interests might combine with the widely-discussed strategic interests of both countries to put trade negotiations on the agenda. In this event, key questions for policy makers would include whether the Lawrence and Chadha (2004)'s finding that both India and the US could gain economically from an FTA still holds, and whether these gains would be increased or reduced if negotiations were to take place after the implementation of the proposed mega-regionals.

The objective of this paper is to provide a preliminary assessment of the potential economic impacts of an FTA between India and the US. For this, we use the Global Trade Analysis Project (GTAP) model (Hertel 1996) (Version 8). GTAP is a relatively standard applied Computable General Equilibrium (CGE) model that is used for a variety of applications, including for studies to evaluate, ex ante, the welfare impacts of FTAs (Hertel, Hummels, Ivanic and Roman 2007). To ensure maximum clarity and transparency, the analysis is intentionally simple and static in order to address key issues such as the nature and extent of trade creation and diversion from an agreement, and the sensitivity of these effects to the presence of other preferential trade agreements.

Because of our focus on simplicity and transparency, the paper does not consider 
dynamic impacts of an FTA, such as the impacts of increased Foreign Direct Investment (FDI) inflows, impacts on productivity growth resulting from access to foreign knowledge, and accelerated domestic reforms (Fukase and Winters 2003). For the same reason, we use standard trade-weighted averages of protection, rather than the more sophisticated optimal aggregation approach outlined in Laborde, Martin and Van der Mensbrugghe (2016). Since the nature of any liberalization to be undertaken is not clear at this stage, the simulation scenarios are based on a uniform assumption designed to explore the possible impact of a far-reaching agreement, i.e., 100 percent Ad Valorem Equivalent (AVE) tariff cuts for goods and 50 percent cuts for services. We use a smaller reduction in barriers on trade in services because many of these barriers are qualitative and difficult to distinguish from non-discriminatory liberalization. In sum, the main focus of the paper is to illustrate mechanisms through which an FTA might cause real income changes.

Following this introduction, Section II examines the underlying patterns of trade and protection in each country. Section III illustrates theories of preferential trade liberalization. Section IV conducts a series of simulations. We first evaluate the potential impacts of an India-US FTA on trade, output and welfare for both countries. Then we investigate how the economic implications of an India-US FTA vary depending on prior agreements. Section V presents a brief conclusion.

\section{Trade and Protection Patterns}

\section{A. General trends}

Figure 1 and Figure 2 show that trade between India and the US has been growing rapidly. US imports from India rose from 13 billion US dollars to 54 billion US dollars during the period 2000 2011, while US exports to India increased from 6 billion US dollars to 32 billion US dollars. Trade in services is especially important in both directions. In particular, exports of services from India to the US have increased dramatically since around 2005. Trade in manufactured goods appears to be growing steadily. Trade in agriculture (including processed agriculture) is relatively small in both directions. Throughout the period, the US has experienced an overall trade deficit 
relative to India. The US had a trade surplus with India in the services sector until 2005, and has had a trade deficit since 2006.

\section{Figure 1. US imports from India}

(Millions of US dollars)

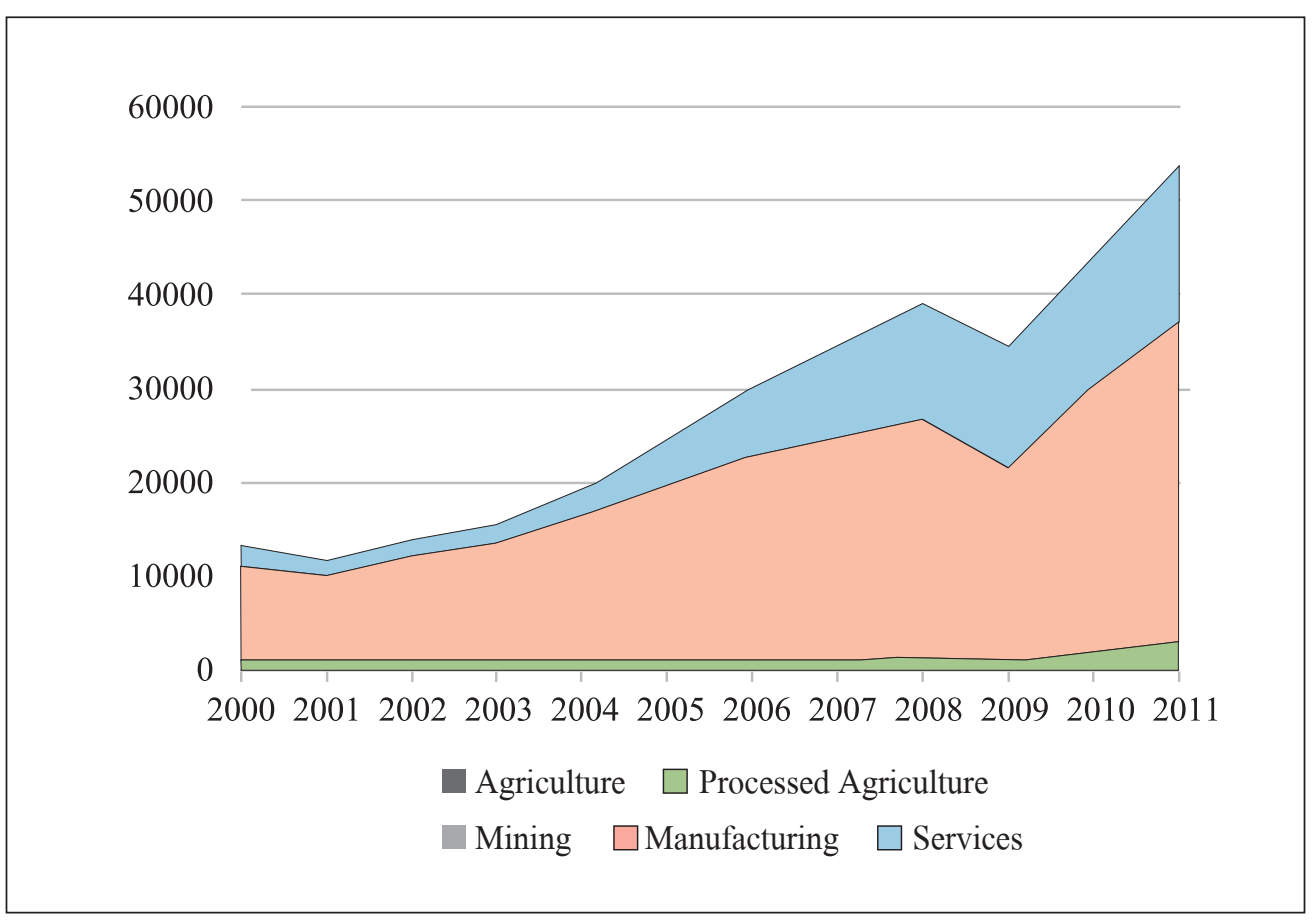

Table 1. US imports from India

(Millions of US dollars)

\begin{tabular}{|l|c|c|c|c|c|c|c|c|c|c|c|c|}
\hline \multicolumn{10}{|c|}{ Year } \\
\hline Economic Sector & $\mathbf{2 0 0 0}$ & $\mathbf{2 0 0 1}$ & $\mathbf{2 0 0 2}$ & $\mathbf{2 0 0 3}$ & $\mathbf{2 0 0 4}$ & $\mathbf{2 0 0 5}$ & $\mathbf{2 0 0 6}$ & $\mathbf{2 0 0 7}$ & $\mathbf{2 0 0 8}$ & $\mathbf{2 0 0 9}$ & $\mathbf{2 0 1 0}$ & $\mathbf{2 0 1 1}$ \\
\hline Agriculture & 548 & 445 & 413 & 406 & 491 & 516 & 517 & 562 & 699 & 554 & 657 & 972 \\
\hline Processed Agriculture & 596 & 573 & 688 & 760 & 804 & 817 & 853 & 860 & 1046 & 852 & 1252 & 2277 \\
\hline Mining & 27 & 38 & 25 & 77 & 57 & 74 & 80 & 44 & 85 & 31 & 47 & 50 \\
\hline Manufacturing & 9941 & 9109 & 11199 & 12351 & 14880 & 18243 & 21214 & 23307 & 24762 & 20303 & 28428 & 33747 \\
\hline Services & 1901 & 1821 & 1817 & 1985 & 2844 & 4985 & 7460 & 9883 & 12498 & 12486 & 14188 & 16921 \\
\hline Total & $\mathbf{1 3 0 1 3}$ & $\mathbf{1 1 9 8 6}$ & $\mathbf{1 4 1 4 2}$ & $\mathbf{1 5 5 8 0}$ & $\mathbf{1 9 0 7 6}$ & $\mathbf{2 4 6 3 5}$ & $\mathbf{3 0 1 2 4}$ & $\mathbf{3 4 6 5 6}$ & $\mathbf{3 9 0 9 1}$ & $\mathbf{3 4 2 2 6}$ & $\mathbf{4 4 5 7 2}$ & $\mathbf{5 3 9 6 7}$ \\
\hline
\end{tabular}

(Source) The UN Comtrade System for the goods data; Bureau of Economic Analysis for the services data, www.bea.gov 


\section{Figure 2. US exports to India}

(Millions of US dollars)

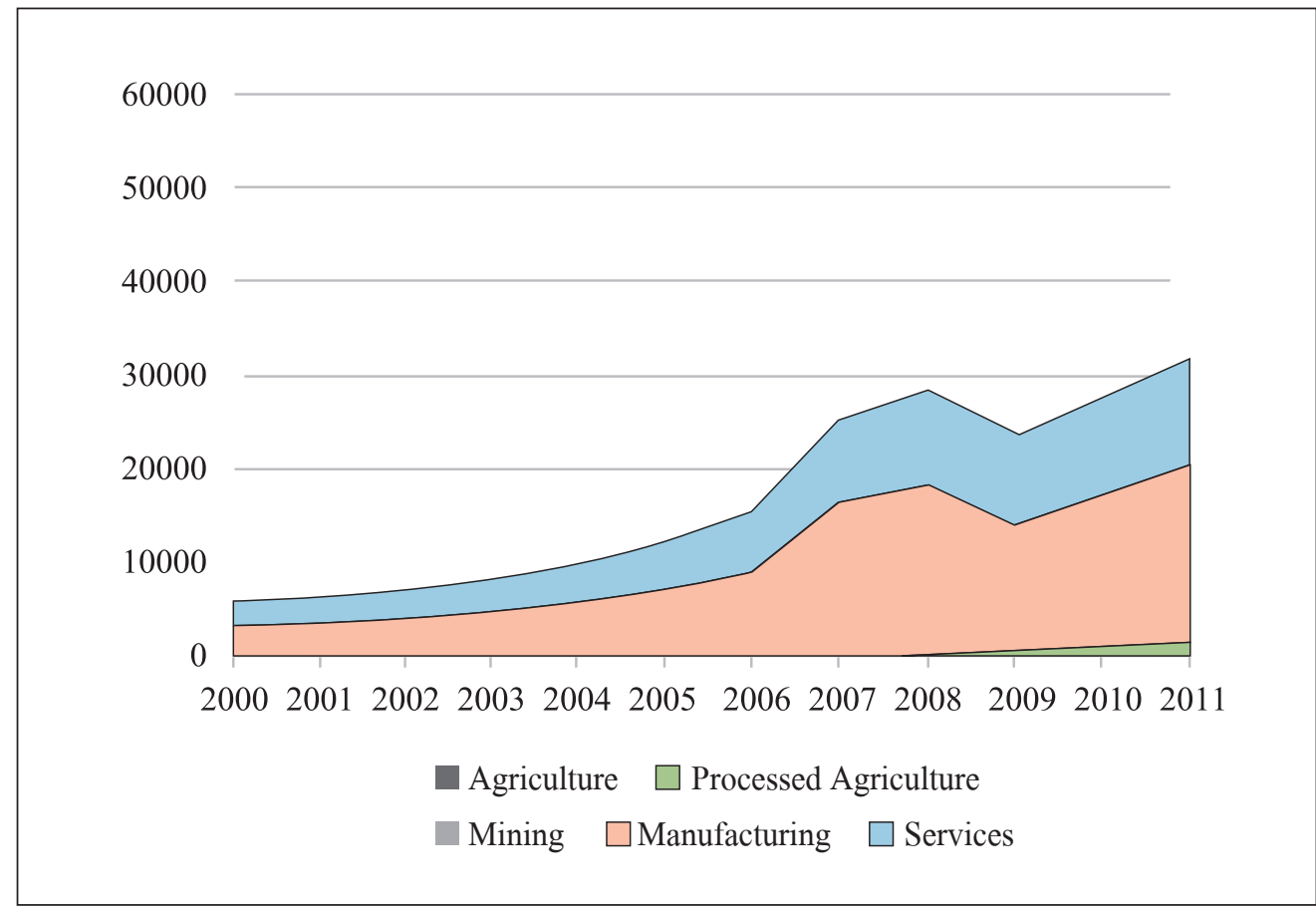

Table 2. US exports to India

(Millions of US dollars)

\begin{tabular}{|l|c|c|c|c|c|c|c|c|c|c|c|c|}
\hline \multicolumn{10}{|c|}{ Year } \\
\hline Economic Sector & $\mathbf{2 0 0 0}$ & $\mathbf{2 0 0 1}$ & $\mathbf{2 0 0 2}$ & $\mathbf{2 0 0 3}$ & $\mathbf{2 0 0 4}$ & $\mathbf{2 0 0 5}$ & $\mathbf{2 0 0 6}$ & $\mathbf{2 0 0 7}$ & $\mathbf{2 0 0 8}$ & $\mathbf{2 0 0 9}$ & $\mathbf{2 0 1 0}$ & $\mathbf{2 0 1 1}$ \\
\hline Agriculture & 119 & 284 & 180 & 256 & 189 & 225 & 287 & 386 & 406 & 473 & 490 & 585 \\
\hline Processed Agriculture & 97 & 72 & 96 & 61 & 65 & 70 & 74 & 79 & 73 & 197 & 306 & 144 \\
\hline Mining & 43 & 26 & 34 & 30 & 145 & 191 & 177 & 142 & 406 & 414 & 569 & 1141 \\
\hline Manufacturing & 3221 & 3203 & 3668 & 4435 & 5460 & 6865 & 8765 & 15934 & 17437 & 12904 & 16335 & 18752 \\
\hline Services & 2580 & 3016 & 3270 & 3776 & 4464 & 5137 & 6587 & 8851 & 10267 & 9945 & 10382 & 11108 \\
\hline Total & $\mathbf{6 0 6 0}$ & $\mathbf{6 6 0 1}$ & $\mathbf{7 2 4 8}$ & $\mathbf{8 5 5 8}$ & $\mathbf{1 0 3 2 3}$ & $\mathbf{1 2 4 8 8}$ & $\mathbf{1 5 8 9 1}$ & $\mathbf{2 5 3 9 2}$ & $\mathbf{2 8 5 8 7}$ & $\mathbf{2 3 9 3 3}$ & $\mathbf{2 8 0 8 3}$ & $\mathbf{3 1 7 3 0}$ \\
\hline
\end{tabular}

(Source) The UN Comtrade System for the goods data; Bureau of Economic Analysis for the services data, www.bea.gov 


\section{B. Trade and protection patterns}

The economic implications of an FTA between India and the US will depend heavily upon the pattern of trade between these two countries as well as their patterns of protection. The patterns of their protection and trade flows will in turn influence the extent of gains and losses due to terms-of-trade effects and the benefits and costs accruing from trade creation and diversion.

Figue 3. Sources of US imports

(in 2007)

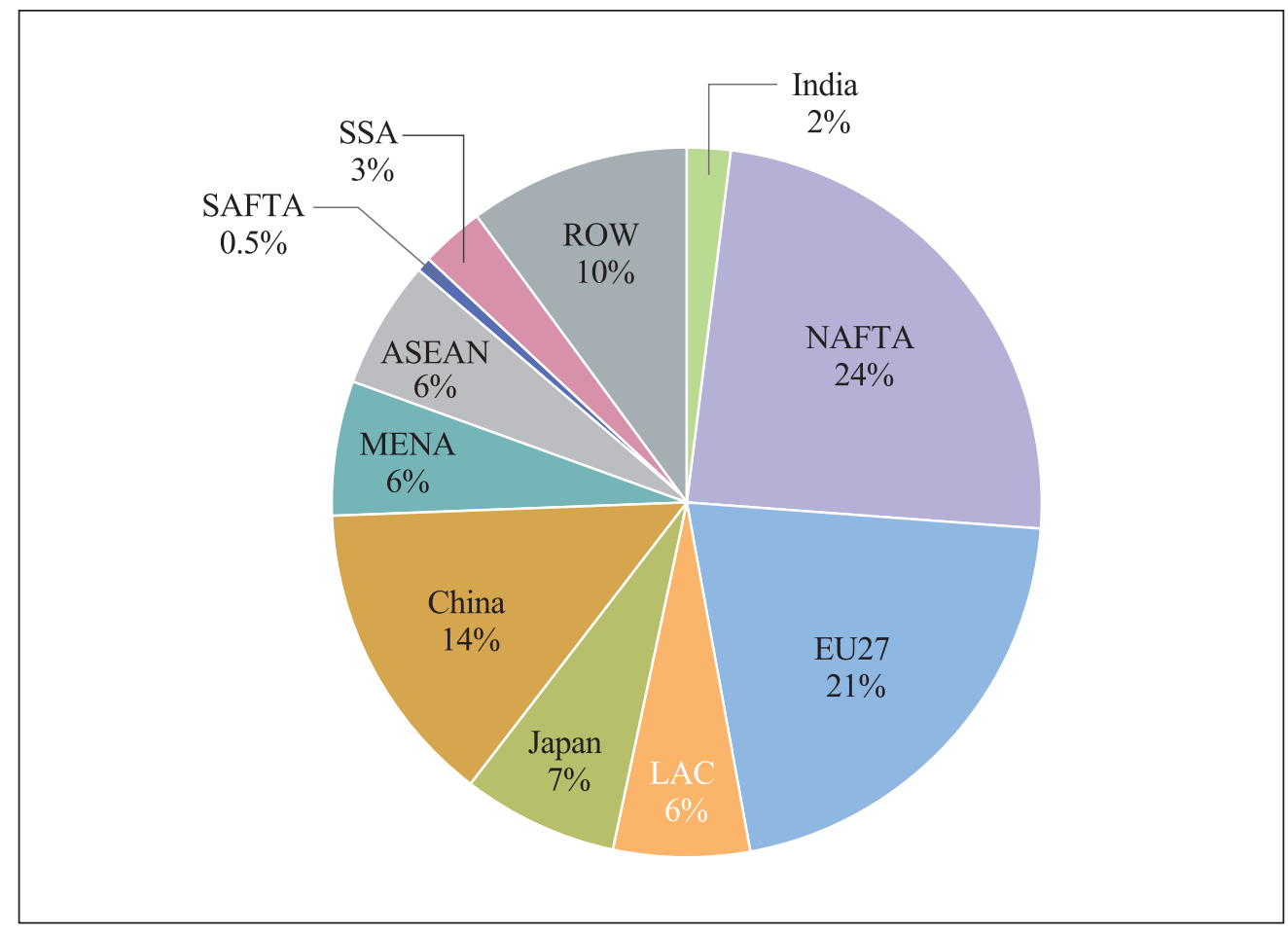

(Notes) (i) NAFTA share consists of Canada and Mexico and does not include the US. SAFTA share does not include India.

(ii) ASEAN: Association of South East Asian Nations, EU: European Union, LAC: Latin America and the Caribbean, MENA: Middle East and North Africa, SA: South Asia, SSA: Sub-Saharan Africa, NAFTA: North American Free Trade Agreement, SAFTA: South Asian Free Trade Area.

(Source) GTAP 8 Database. 
Figure 4. Destinations of US exports

(in 2007)

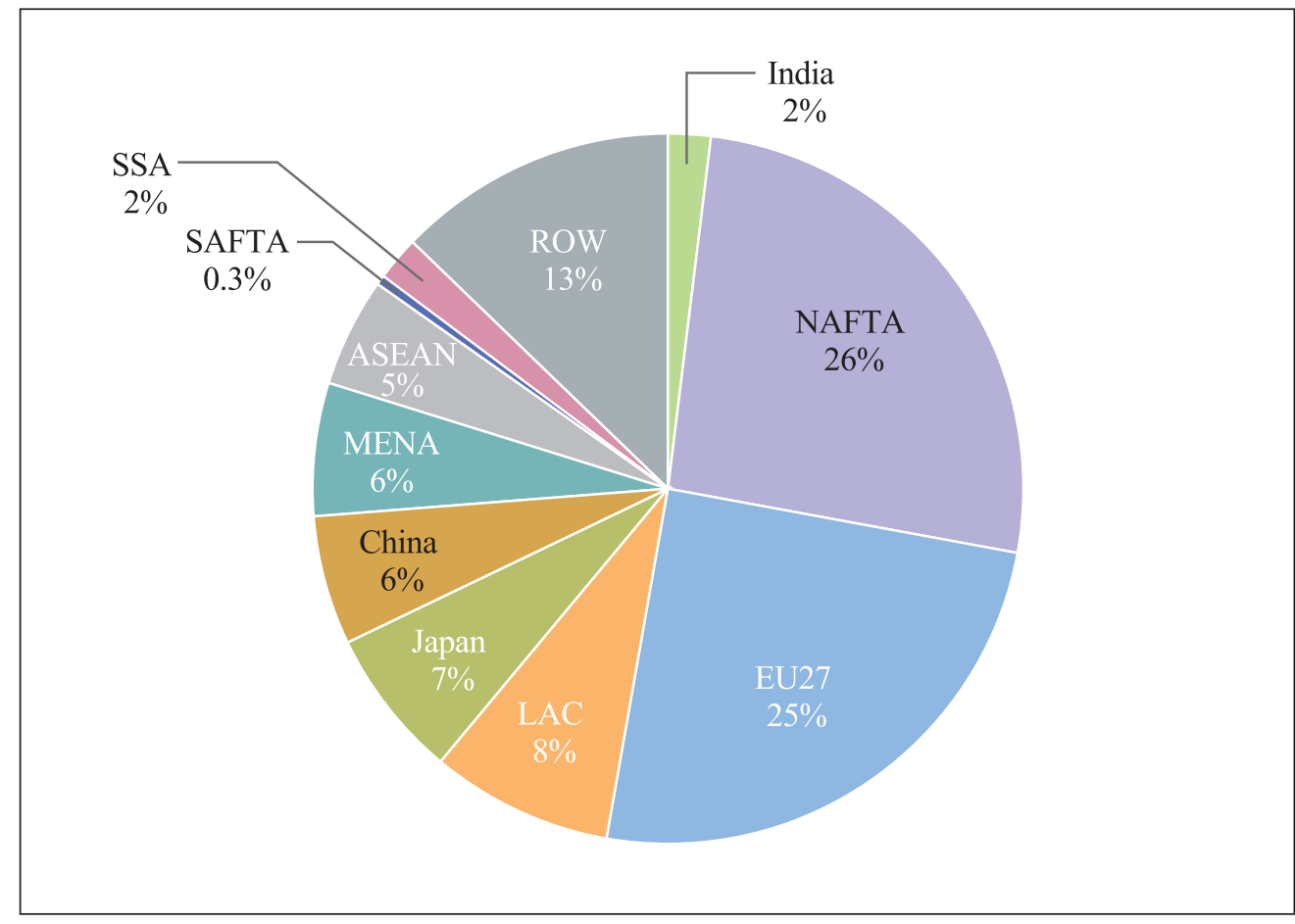

(Notes) (i) NAFTA share consists of Canada and Mexico and does not include the US. SAFTA share does not include India.

(ii) ASEAN: Association of South East Asian Nations, EU: European Union, LAC: Latin America and the Caribbean, MENA: Middle East and North Africa, SA: South Asia, SSA: Sub-Saharan Africa, NAFTA: North American Free Trade Agreement, SAFTA: South Asian Free Trade Area.

(Source) GTAP 8 Database.

Figure 3 and Figure 4 show the sources and destinations of US imports and exports by its trading partners for the year 2007 constructed from the GTAP 8 database. The figures show that India constitutes around 2 percent of US imports and exports. The US's North American Free Trade Agreement (NAFTA) partners, namely Canada and Mexico combined, are the largest sources and destinations of US trade flows (representing 24 percent of imports and 26 percent of exports), followed by the 27 member European Union (EU) in both directions (21 percent of US imports and 25 percent of exports). 


\section{Figure 5. Sources of India's imports}

(in 2007)

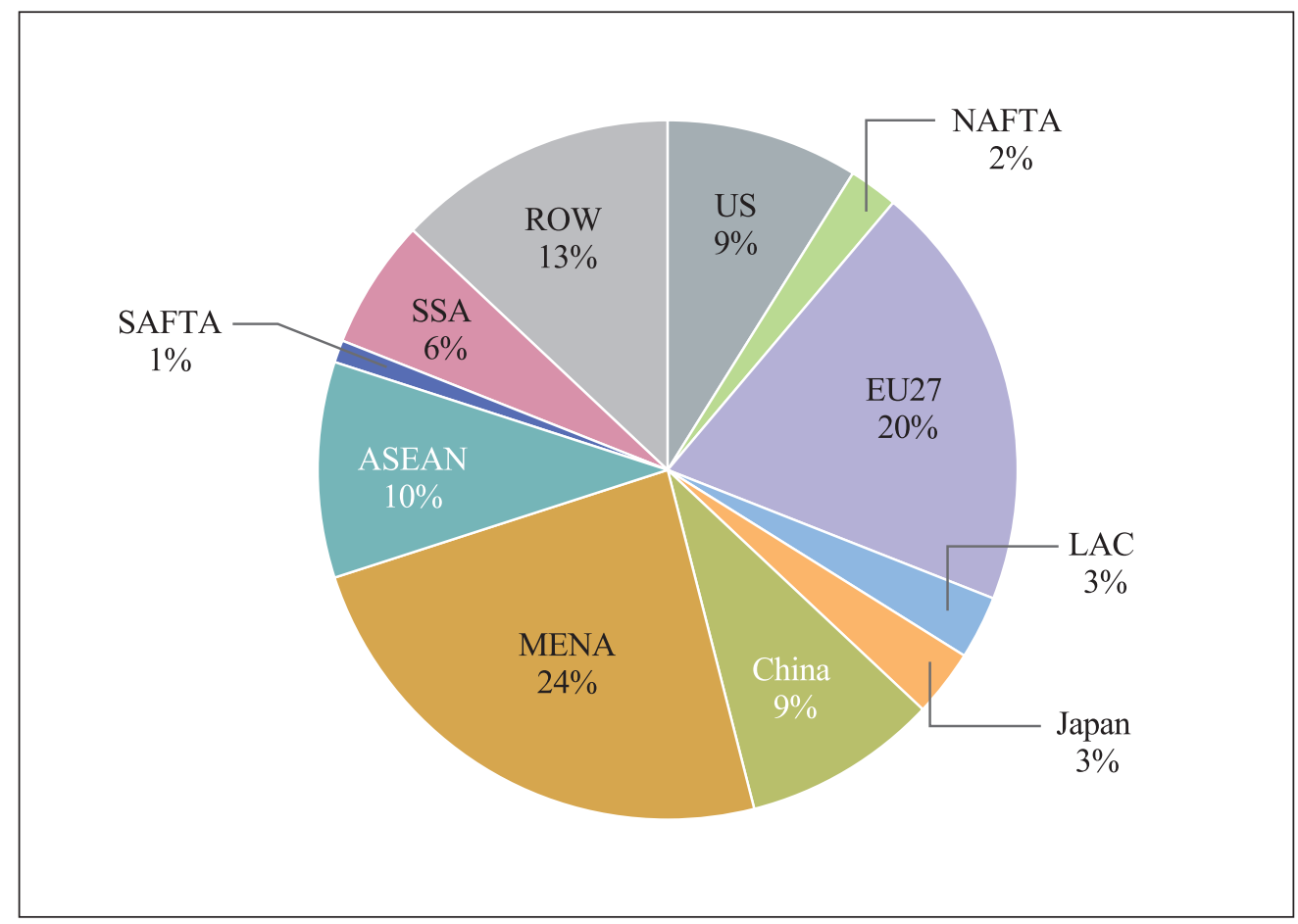

(Notes) (i) NAFTA share consists of Canada and Mexico and does not include the US. SAFTA share does not include India.

(ii) ASEAN: Association of South East Asian Nations, EU: European Union, LAC: Latin America and the Caribbean, MENA: Middle East and North Africa, SA: South Asia, SSA: Sub-Saharan Africa, NAFTA: North American Free Trade Agreement, SAFTA: South Asian Free Trade Area.

(Source) GTAP 8 Database. 


\section{Figure 6. Destinations of India's Exports}

(in 2007)

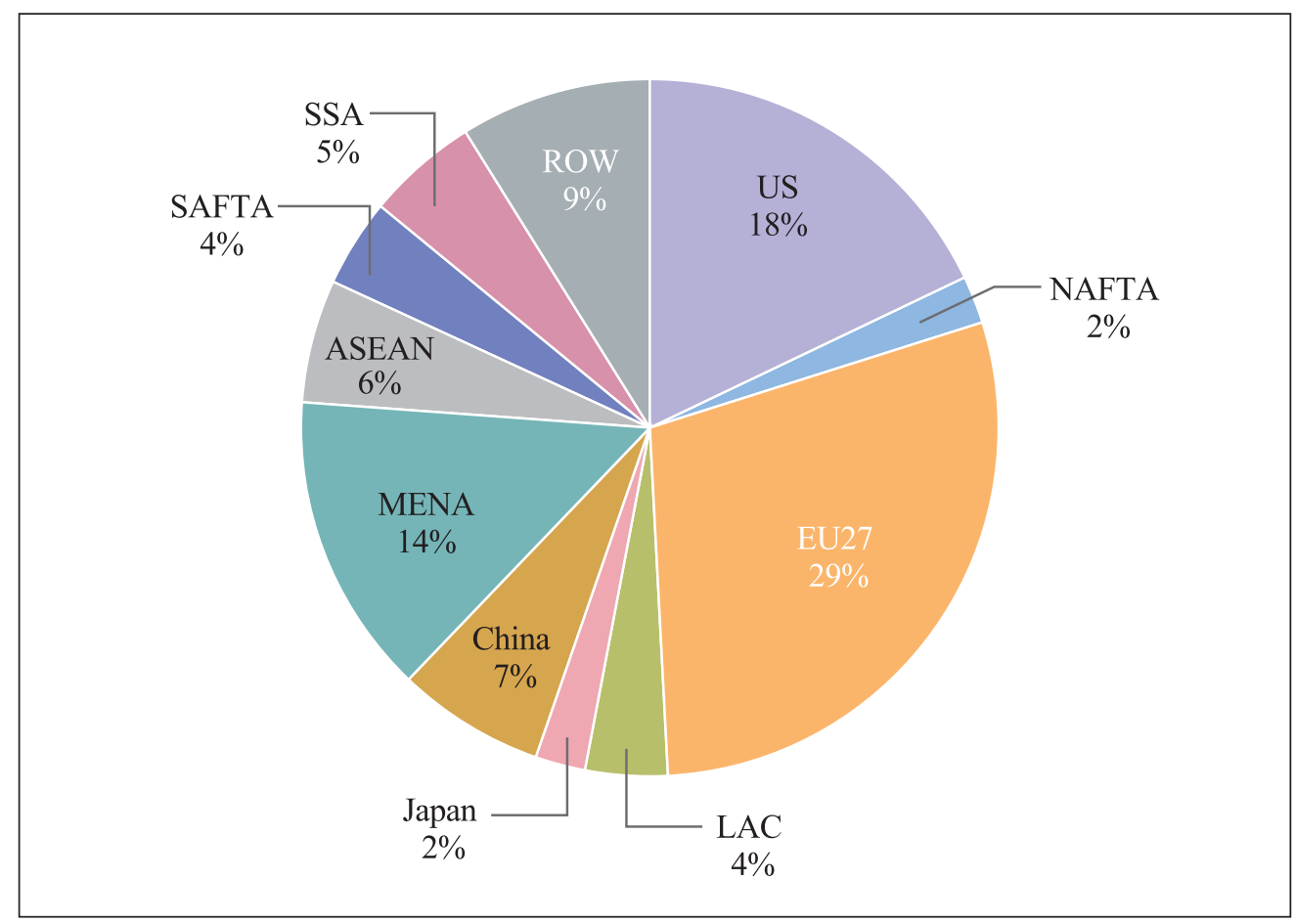

(Notes) (i) NAFTA share consists of Canada and Mexico and does not include the US. SAFTA share does not include India.

(ii) ASEAN: Association of South East Asian Nations, EU: European Union, LAC: Latin America and the Caribbean, MENA: Middle East and North Africa, SA: South Asia, SSA: Sub-Saharan Africa, NAFTA: North American Free Trade Agreement, SAFTA: South Asian Free Trade Area.

(Source) GTAP 8 Database.

Figure 5 and Figure 6 show that the US is much more important as a trading partner for India, accounting for 9 percent of imports and 18 percent of exports, respectively. The EU is the most important import source and export distination for India, constituting 20 percent and 29 percent of India's imports and exports, respectively. 


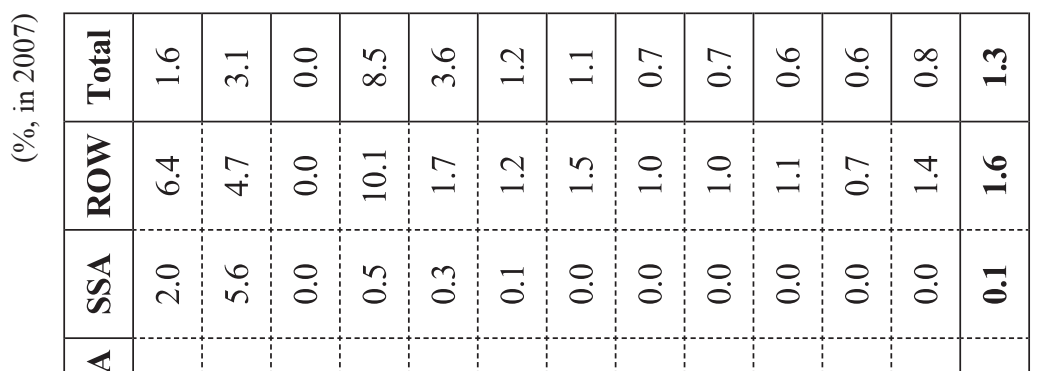

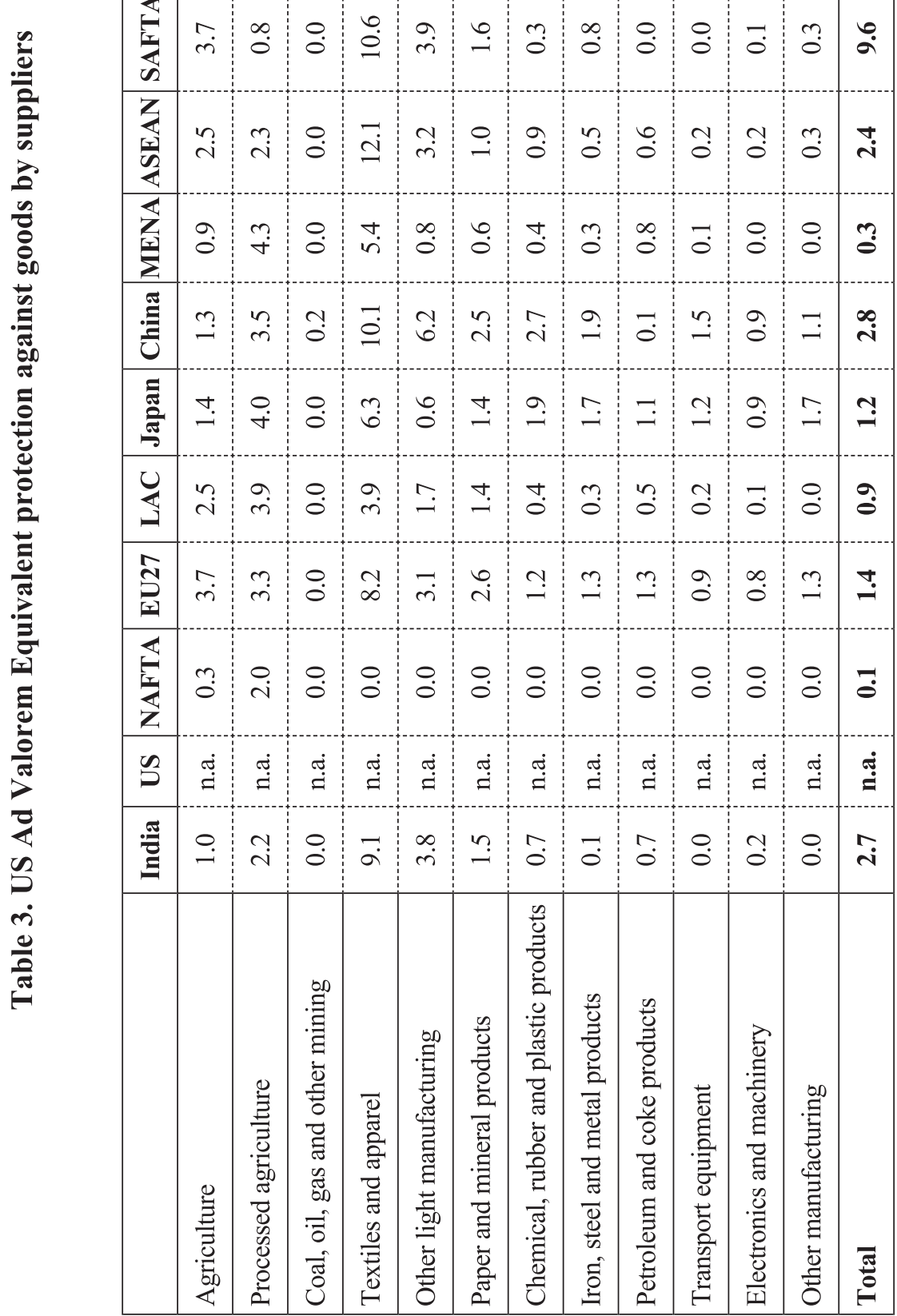


हิ

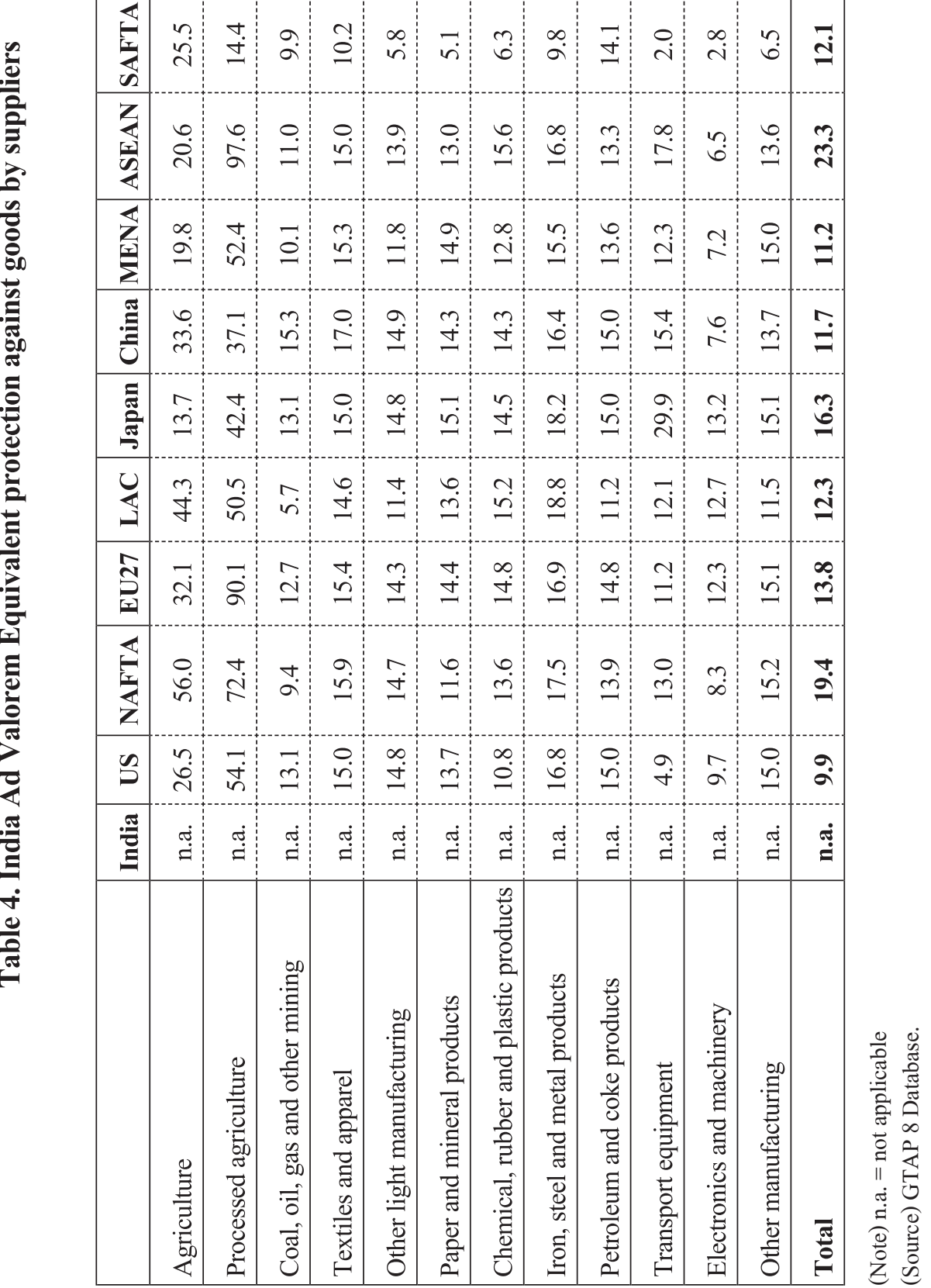


Column 1 in Table 3 shows US Ad Valorem Equivalent (AVE) tariff rates against India's goods, for which reductions would increase US imports from India by the sectors used in the analysis. ${ }^{1}$ The remaining columns of Table 3 show the barriers that apply to other US trading partners - these exports to the US are likely to be reduced by an IndiaUS FTA and associated US tariff revenues would also be reduced, with consequent reductions in economic welfare. An important feature of the GTAP 8 database is the use of protection data which include a comprehensive treatment of trade preferences resulting from Preferential Trade Arrangements (PTAs) as well as the conversion of specific tariffs for both agricultural and non-agricultural goods (Guimbard, Jean, Mimouni and Pichot 2012). Overall, the average AVE rate of protection in the US is relatively low at 1.3 percent. The variation of tariff rates by source countries reflects both preferential schemes and the composition of US imports. The US AVE protection of 2.7 percent against India's goods is higher than average and the US retains particularly high barriers in the textiles and apparel sector (9.1 percent). In contrast, the US grants duty-free access to NAFTA partners for their apparel and textile products and applies substantially lower tariffs against the SSA region ( 0.5 percent) which reflects particularly the preferential rates under the African Growth and Opportunity Act (AGOA). As the US FTAs with Morocco, Chile, and Central America all allowed for immediate duty-free access to textile and apparel products meeting the agreements' rules of origin (Lawrence and Chadha 2004), a similar agreement with India — or, better, one that does not include restrictive rules of origin - would give Indian producers of textile and apparel products a competitive advantage in the US market.

Table 4 shows that India's AVE tariffs are generally high (13.8 percent on average), and are particularly high in the agricultural sectors against exports from all regions. India's AVE of 9.9 percent against US goods is lower than those for India's other partners, while the tariffs against some of its trading partners are especially high, for instance, 23.3 percent against its ASEAN suppliers. This is particularly important because trade diversion is more likely to generate costs when the protection against imports from other partners exceeds that from the country for which import barriers are being reduced.

\footnotetext{
Throughout the paper, the 57 GTAP sectors are aggregated into 13 more manageable categories as defined in the Working Paper version of this paper at www.worldbank.org (Fukase and Martin, 2015).
} 


\begin{tabular}{|c|c|c|c|c|c|c|c|c|c|c|c|c|c|}
\hline 吾 & $\stackrel{\nabla}{\bullet}$ & $\ddot{n}$ & mo & $\stackrel{\bullet}{+}$ & $\bar{i}$ & $\stackrel{\infty}{-}$ & $\stackrel{g}{=}$ & $\stackrel{\infty}{-}$ & $\stackrel{+}{i}$ & $\stackrel{+}{i}$ & $\stackrel{\circ}{\mathrm{i}}$ & $\vec{i}$ & mo \\
\hline \begin{tabular}{l}
3 \\
0 \\
\cline { 1 - 1 }
\end{tabular} & $\underset{\sigma}{\infty}$ & $\overrightarrow{\dot{i}}$ & $\tilde{o}$ & ఫે & $\begin{array}{l}\infty \\
\dot{r}\end{array}$ & $\vec{i}$ & ஸे & $\stackrel{\circ}{-}$ & $\ddot{n}$ & $\stackrel{\circ}{\forall}$ & $\stackrel{n}{\sim}$ & $\vec{n}$ & 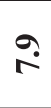 \\
\hline 放 & $\vec{n}$ & $\stackrel{N}{\beth}$ & $\stackrel{r}{r}$ & $\stackrel{N}{2}$ & $\ddot{n}$ & $\stackrel{\circ}{\infty}$ & n? & $\begin{array}{l}\infty \\
\infty\end{array}$ & $?$ & $\stackrel{\nabla}{\sigma}$ & $\stackrel{?}{+}$ & $\ddot{\sim}$ & $\stackrel{2}{r}$ \\
\hline 底 & $\hat{i}$ & $\stackrel{\circ}{\stackrel{ }{\Sigma}}$ & $\begin{array}{l}\dot{v} \\
\dot{r}\end{array}$ & $a$ & $\ddot{n}$ & $\stackrel{t}{\stackrel{0}{0}}$ & $\hat{\infty}$ & $\stackrel{\circ}{\circ}$ & $\stackrel{\varrho}{g}$ & $\stackrel{r}{r}$ & $\underset{\infty}{\infty}$ & $\stackrel{\infty}{\stackrel{0}{0}}$ & $\infty$ \\
\hline$\sum_{2}^{Z}$ & $\vec{n}$ & $a$ & Э & $\vec{\infty}$ & is & $\stackrel{+}{\forall}$ & $n$ & $\stackrel{\circ}{r}$ & $\stackrel{\infty}{-}$ & $\stackrel{\circ}{\circ}$ & oे & $\stackrel{\infty}{\infty}$ & $\ddot{m}$ \\
\hline 玄 & min & $\stackrel{0}{\check{I}}$ & 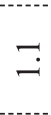 & $\begin{array}{r}\dot{r} \\
\dot{n}\end{array}$ & $\overrightarrow{0}$ & $\begin{array}{l}\mathscr{\sigma} \\
\stackrel{+}{*}\end{array}$ & $\stackrel{\nabla}{+}$ & $\stackrel{\infty}{\oplus}$ & $\begin{array}{l}0 \\
i\end{array}$ & $\stackrel{\circ}{\circ}$ & $\stackrel{\infty}{\dot{r}}$ & $\stackrel{\vec{v}}{\sim}$ & $\ddot{q}$ \\
\hline 苞 & $\stackrel{?}{=}$ & $\ddot{n}$ & $\tilde{0}$ & 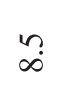 & $\stackrel{\circ}{\forall}$ & $\underset{\sim}{\sim}$ & $\begin{array}{r}\stackrel{n}{ \pm} \\
\text { I }\end{array}$ & $\stackrel{\sim}{\sim}$ & $\stackrel{0}{0}$ & $\underset{\sigma}{\infty}$ & $\stackrel{m}{m}$ & $\stackrel{0}{\stackrel{0}{0}}$ & 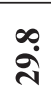 \\
\hline 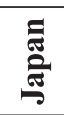 & $\stackrel{\eta}{n}$ & $\stackrel{\circ}{\dot{m}}$ & $\stackrel{0}{\circ}$ & $\stackrel{\circ}{\circ}$ & $\stackrel{\infty}{\oplus}$ & ก้ & $\because$ & $\grave{o}$ & ํ. & $\stackrel{\circ}{\circ}$ & $\overrightarrow{0}$ & 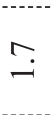 & $\stackrel{\theta}{\circ}$ \\
\hline$\underset{J}{\bigcup}$ & $\stackrel{ }{\circ}$ & $\stackrel{\circ}{\sim}$ & $\stackrel{0}{-}$ & $\vec{\infty}$ & $\stackrel{\nabla}{\sim}$ & $\stackrel{\infty}{\sim}$ & $\underset{\sim}{\stackrel{ナ}{r}}$ & $\stackrel{\infty}{a}$ & $\begin{array}{l}0 \\
\dot{n}\end{array}$ & $m_{\infty}^{\infty}$ & $\stackrel{\infty}{6}$ & $\stackrel{m}{ \pm}$ & مִ \\
\hline$\stackrel{\widehat{ડ}}{\widehat{S}}$ & $\hat{r}$ & $\begin{array}{l}0 \\
\dot{I}\end{array}$ & $\stackrel{0}{0}$ & $\stackrel{\circ}{\circ}$ & ָָ & $\stackrel{\circ}{-}$ & $\stackrel{m}{\sim}$ & $\stackrel{0}{\circ}$ & 9 & $\ddot{m}$ & 二 & 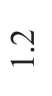 & $\ddot{i}$ \\
\hline 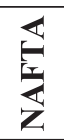 & $\ddot{n}$ & $\stackrel{\circ}{=}$ & $\stackrel{0}{0}$ & $\stackrel{0}{0}$ & $\stackrel{\circ}{0}$ & $\stackrel{0}{\circ}$ & $\stackrel{\circ}{\circ}$ & $\stackrel{\circ}{\circ}$ & $\stackrel{\circ}{0}$ & $\ddot{0}$ & $\stackrel{0}{0}$ & $\stackrel{\circ}{\circ}$ & $\hat{\theta}$ \\
\hline $\mathscr{\Omega}$ & $\stackrel{\text { త্ }}{\text { d }}$ & 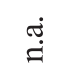 & $\stackrel{\text { త্ }}{~}$ & 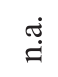 & 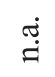 & $\stackrel{\text { త্் }}{~}$ & $\stackrel{\text { త্ }}{\text {. }}$ & 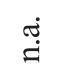 & $\stackrel{\text { త্ }}{\text {. }}$ & $\stackrel{\text { త্் }}{\text {. }}$ & $\stackrel{\text { త্ }}{\text { I }}$ & $\stackrel{\overbrace{}}{\dot{\Theta}}$ & $\stackrel{\leftrightarrow}{\stackrel{\leftrightarrow}{g}}$ \\
\hline 鸮 & 吕 & 茫 & $\vec{r}$ & $\begin{array}{l}0 \\
i\end{array}$ & $\stackrel{\infty}{ \pm}$ & $\ddot{n}$ & $\stackrel{\infty}{0}$ & $\stackrel{\infty}{\bullet}$ & $\begin{array}{l}0 \\
\text { in }\end{array}$ & $\stackrel{\vartheta}{\dot{\gamma}}$ & $\hat{\sigma}$ & $\stackrel{0}{\mathscr{1}}$ & $\hat{\sigma}$ \\
\hline & 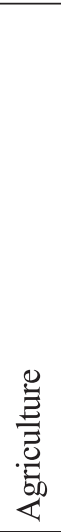 & 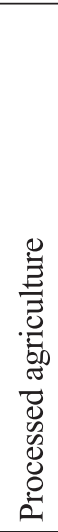 & 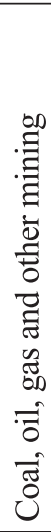 & 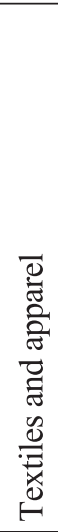 & 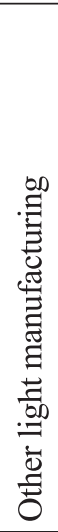 & 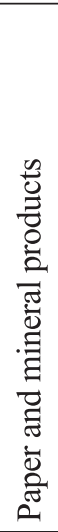 & 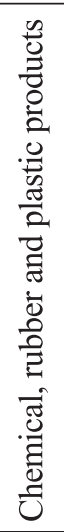 & 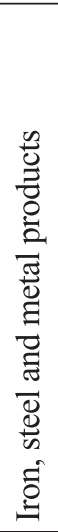 & 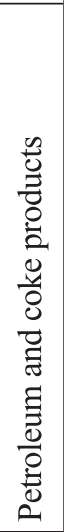 & 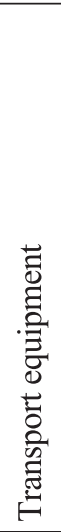 & 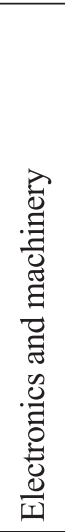 & 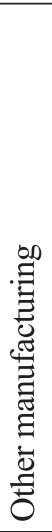 & है \\
\hline
\end{tabular}




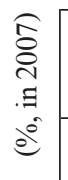

\begin{tabular}{|c|c|c|c|c|c|c|c|c|c|c|c|c|c|}
\hline हี & $\begin{array}{l}0 \\
\text { I }\end{array}$ & $\begin{array}{l}0 \\
\infty\end{array}$ & ? & ๙ุa & $\stackrel{\infty}{\infty}$ & $\because$ & $\underset{\sim}{0}$ & $\stackrel{\circ}{\dot{m}}$ & 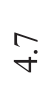 & $\vec{r}$ & $\begin{array}{l}0 \\
i\end{array}$ & $\stackrel{0}{0}$ & $\stackrel{\infty}{+}$ \\
\hline ב) & 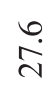 & $\stackrel{\circ}{=}$ & rֶ & $\underset{\sim}{\stackrel{\nabla}{*}}$ & $\stackrel{?}{+}$ & $\stackrel{\infty}{\dot{m}}$ & $\stackrel{\nabla}{r}$ & ָָ & ñ. & $\stackrel{\circ}{+}$ & $\stackrel{\circ}{\circ}$ & $n$ & \\
\hline$\overleftrightarrow{\approx}$ & $\stackrel{n}{0}$ & $\begin{array}{l}\bullet \\
\stackrel{ \pm}{ \pm}\end{array}$ & $\stackrel{r}{n}$ & $m_{0}^{\infty}$ & $\stackrel{n}{\simeq}$ & 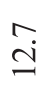 & $\stackrel{\infty}{0}$ & $\stackrel{\sim}{\sim}$ & $\stackrel{\infty}{\sim}$ & 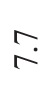 & $\begin{array}{l}\infty \\
\dot{n}\end{array}$ & 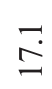 & \\
\hline
\end{tabular}

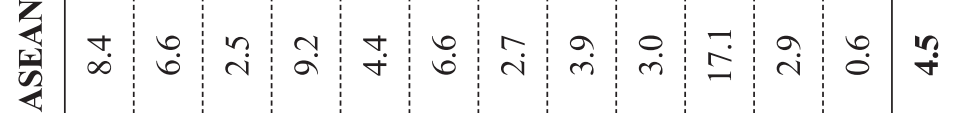

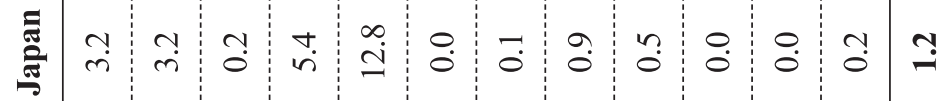

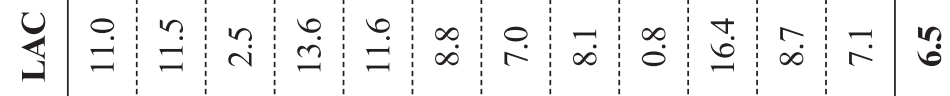

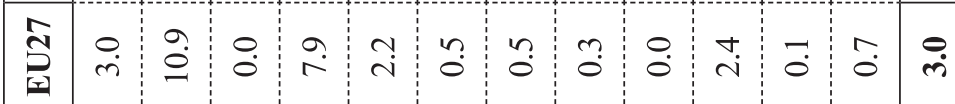

荘

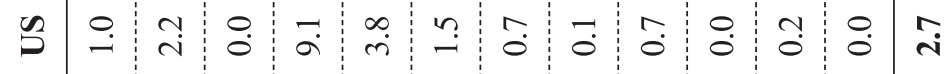


On the export side, the removal of barriers by a country's FTA partner is a key factor in reaping gains from reciprocal trade liberalization. The higher the initial barriers imposed by a country's trading partner, the larger the (potential) scope of improved market access resulting from an FTA, and the bigger the potential terms-of-trade gains to the exporter. Table 5 compares the AVE protection that US exporters encounter in the Indian market with the protection they face in other markets. Overall, US exports face on average a tariff of 5.3 percent across all export markets. The protection that US exporters face in the Indian market ( 9.9 percent) is nearly double the average. This structure of protection suggests that the US is likely to gain greatly from improved market access resulting from an India-US FTA. Similarly, Table 6 compares the protection that Indian exporters face in the US market and those in India's other export destinations. Indian exporters face on average of 4.8 percent of protection globally against their exports of goods. Since US barriers against Indian exports (2.7 percent) are relatively low overall, India's terms of trade gains on the export side may be relatively small on averagealthough the potential volumes of trade are very large. On the other hand, since the US is among India's leading export destinations (Figure 6) and the US tariffs against Indian Labor-intensive goods remain high, Indian market access to the US is likely to remain an important issue in negotiations.

Many economists believe that the potential gains from liberalization in the service sector may be larger than gains available from liberalization of the trade in goods (Gervais and Jensen 2013 for the US, Konan and Maskus 2006 for Tunisia and Chadha, Brown, Deardorff and Stern 2000 for India). The scope for gains from the trade liberalization in services may be higher since barriers to trade in services tend to be higher than the remaining barriers to trade in goods. Moreover, it is increasingly recognized that service sector trade liberalization not only directly affects service production and trade, but also has positive impacts on productivity or exports of goods, especially in developing countries (Arnold, Javorcik, Lipscomb and Mattoo 2016, Cebula, Mazumdar and NairReichert 2011, Fukui and McDaniel 2010, Konan and Maskus 2006 and Robinson, Wang and Martin 2002).

Analysis of the impacts of the liberalization of trade in services is severely constrained by the lack of reliable trade and protection data on service. The estimates of barriers to trade in services vary widely in the literature, depending on methodologies, how the barriers are defined, which sectors are included and whether the barriers include nondiscriminatory impediments or apply only against foreign suppliers. However, many economists generally view barriers to services in India to be high, and those in the US 
to be low (Borchert, Gootiiz and Mattoo 2014, Gervais and Jensen 2013, Hufbauer, Schott and Wong 2010, and Petri, Plummer and Zhai 2012). ${ }^{2}$ As the best available educated guesstimate at the time of writing, we used the tariff equivalents of barriers to services reported in Hufbauer, Schott and Wong (2010). According to these measures, the tariff equivalents of barriers to services are estimated to be 6.03 percent for the US and 68.06 percent for India. In future work, it would be desirable to consider ad valorem equivalents of barriers to services that are of the type estimated by Jafari and Tarr (2014).

\section{Theory of Preferential Trade Liberalization}

In this section, we outline the basic framework used to evaluate the effects of reciprocal liberalization between the US and India (Fukase and Martin 2001). On the import side, the concepts of trade creation and trade diversion are central to the evaluation of discriminatory trade liberalization. Trade creation measures the gains from expanding trade in the products being liberalized. Trade diversion, in contrast, reflects the reductions in trade of products disadvantaged by preferential liberalization, particularly the losses of government revenue associated with this phenomenon.

\footnotetext{
${ }^{2}$ For instance, according to the Services Trade Restrictions Database which was released recently by the World Bank, India is found to be among the countries that have the most restrictive policies in services while service trade in the US is found to be generally open (Borchert et al. 2014). The Services Trade Restrictions Indices (STRI), which range from 0 to 100, are found to be 17.7 and 65.7 for the US and India respectively. However, the STRI does not cover cross-border trade in business processing services associated with the outsourcing phenomenon.
} 
Figure 7. Welfare impacts of US liberalization of imports from India

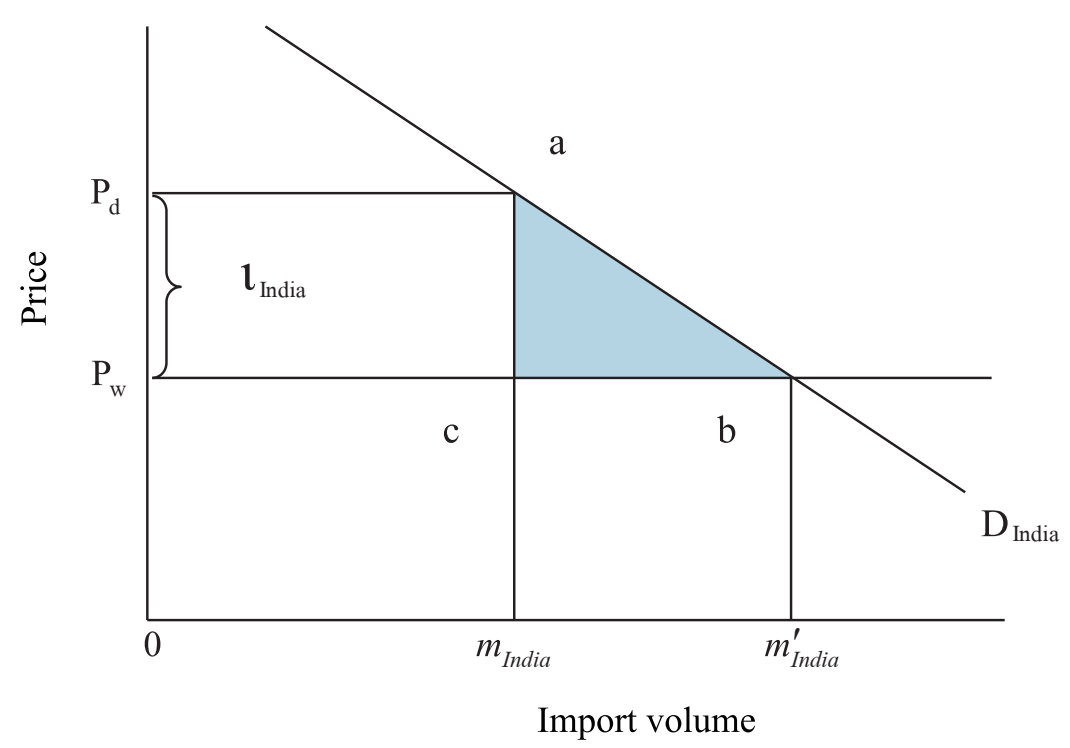

Figure 8. Welfare impact of preferential liberalization on imports from non-partner countries

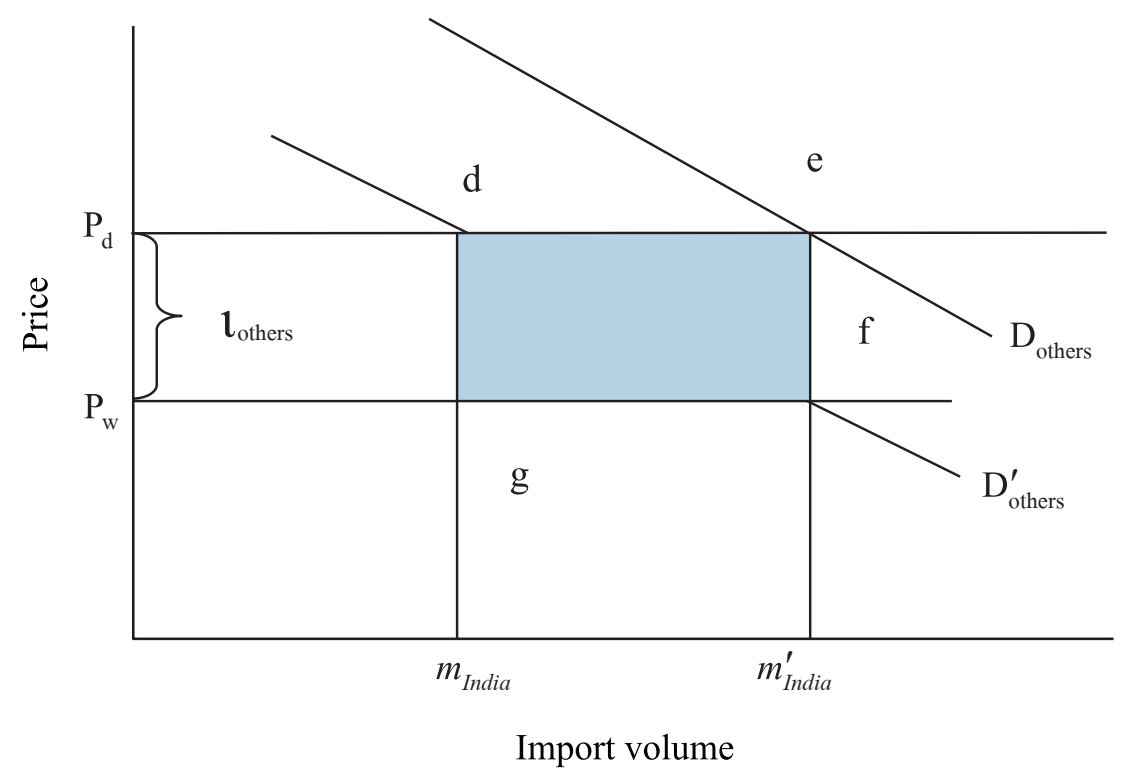


To measure these impacts, we first consider the effects of changes in the tariffs that the US levies on its imports from India (or vice versa). To aid an understanding of the concept of trade creation, the market for goods imported by the US from India is illustrated in Figure 7. In the initial equilibrium, the US imposes a tariff $\tau_{\text {India }}\left(\mathrm{P}_{\mathrm{d}}=\mathrm{P}_{\mathrm{w}}+\right.$ $\tau_{\text {India }}$ where $\mathrm{P}_{\mathrm{d}}$ and $\mathrm{P}_{\mathrm{w}}$ are the domestic price and the world price respectively). Let us now eliminate the tariff on imports from India. This reduces tariff revenues on initial imports from India by $\mathrm{P}_{\mathrm{d}} \mathrm{acP} \mathrm{P}_{\mathrm{w}}$. However, the gains to consumers are greater as they increase the quantity of the Indian goods they purchase. Following the decline in the domestic price, consumers move down the (compensated) demand curve for Indian goods, $\mathrm{D}_{\text {India }}$ from initial quantity $\mathrm{m}$ to final quantity $\mathrm{m}$ '. Consumers gain the value $\mathrm{P}_{\mathrm{d}} \mathrm{acP} \mathrm{P}_{\mathrm{w}}$ that would formerly have been paid to the government in tariffs. In addition, consumer surplus increases by the area abc. The net gain to the US in this market can be approximated by the shaded area abc. This is the welfare benefit from trade creation.

If the import distortion being liberalized is the only distortion in the economy, then the welfare impacts of liberalization can be analyzed by considering only the trade creation effects depicted above. If, however, there are distortions in other markets, the problem is one of second best and the impacts of liberalization on trade flows through these barriers must be considered. Perhaps the best known type of the second-best welfare effect when considering a preferential trade agreement is trade diversion. In the analytical framework used in this study, this potential source of loss is readily seen by examining conditions in the market for imports from non-partner countries, as represented in Figure 8. Assuming that imports from non-partner countries are substitutes for imports from partner countries, the reduction in the price of imports from India shown in Figure 8 leads to a reduction in the demand for goods from non-partner countries, shifting the demand curve for these goods from $\mathrm{D}_{\text {others }}$ to $\mathrm{D}_{\text {others }}^{\prime}$. This has adverse welfare consequences that can be measured by the tariff revenues collected on non-partner imports. The welfare loss to the US is also the consequent loss in tariff revenues, which is shown by the area defg.

Whether there is a net gain or loss to the importing country depends on the relative sizes of the two shaded areas. Clearly, the gains from trade creation will be larger, the higher the rate of protection initially applied on these trade flows, and the more priceresponsive the total domestic demand for these goods. Other things equal, they will also be larger on bigger initial trade flows. In contrast, the higher the tariffs applied in the non-partner imports, and the greater the reduction in the quantity of imports from these markets, the greater the trade diversion costs are likely to be.

Terms of Trade (TOT) effects, which are defined as a change in export prices relative 
to import prices, are another key component of welfare changes, as an improvement in the terms of trade contributes to welfare gains. In the case of reciprocal liberalization, the TOT gains emerging from improved access to the partner's market are likely to be central in evaluating the welfare consequence on the export side. In Figure 9, it is shown that the reduction in Indian tariffs on exports from the US shifts India's import demand curve for exports from ED to ED'. This causes the price received by US exporters to rise from $\mathrm{P}$ to $\mathrm{P}^{\prime}$. The result is an increase in the price received for these exports and an increase in the volume of exports from the US to India (shaded area hijk).

For large traders such as the US and India, there are other potentially important terms-of-trade effects. ${ }^{3}$ An increase in a country's import demand that is associated with liberalization may lead to a rise in its import prices, causing the country's TOT to deteriorate. Liberalization also causes a reduction in input costs and hence improved competitiveness and exports. If this increase in export supplies causes a decline in export prices in both partner and non-partner markets, there may be a terms of trade effect that needs to be incorporated into the analysis.

${ }^{3}$ The GTAP model assumes that products are differentiated by origin (the Armington assumption). 
Figure 9. Trade impacts of improved access to a partner

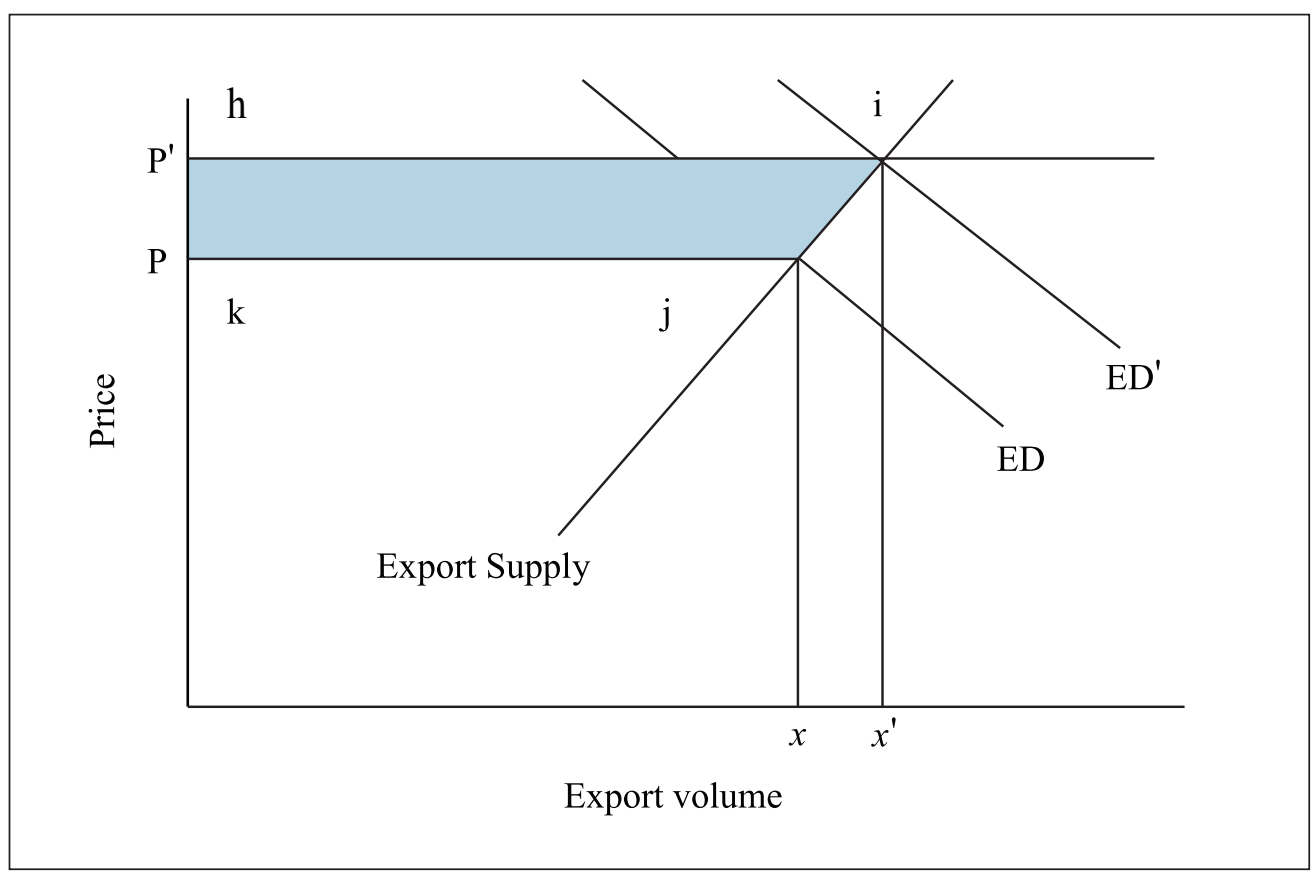

The net effect on the overall TOT depends primarily on the difference between the TOT loss resulting from trade expansion and the TOT gains from preferential access to the partner's market. All of the impacts of discriminatory trade liberalization that are outlined above need to be considered simultaneously in forming an overall assessment of the proposed approach. While diagrams of the type shown above aid understanding, they do not provide a practical basis for making an overall evaluation since many of the relationships depicted are interdependent. By contrast, quantitative models such as GTAP allow all of these effects to be considered together. 


\section{Results}

\section{A. US-India FTA}

\section{Trade and output effects}

In this section, we implement a series of simulations pertaining to a potential India-US FTA. We have aggregated the original 57 GTAP sectors and 113 countries/ regions into 13 broad categories (see footnote 1) and 15 regions, namely, the US, India, Australia/New Zealand, Canada/Mexico, EU27, Chile/Peru, Rest of LAC, Japan, China, ASEAN (TPP members), ASEAN (non TPP members), MENA, SAFTA, SSA and Others. Since the nature of liberalization of goods and services trade may be different, we first simulate the impacts of liberalization of goods and services separately.

Table 7. Trade effects with 100 percent AVE protection cut for goods

$(\%)$

\begin{tabular}{|l|c|c|c|c|c|c|}
\hline & $\begin{array}{c}\text { Exports } \\
\text { from the US } \\
\text { to India }\end{array}$ & $\begin{array}{c}\text { Exports } \\
\text { from India } \\
\text { to the US }\end{array}$ & $\begin{array}{c}\text { Total } \\
\text { US } \\
\text { imports }\end{array}$ & $\begin{array}{c}\text { Total } \\
\text { Indian } \\
\text { Imports }\end{array}$ & $\begin{array}{c}\text { Total } \\
\text { US } \\
\text { Exports }\end{array}$ & $\begin{array}{c}\text { Total } \\
\text { Indian } \\
\text { exports }\end{array}$ \\
\hline Agriculture & 183.2 & 5.3 & 0.5 & 10.1 & 0.9 & 0.2 \\
\hline Processed agriculture & 718.8 & 11.6 & 0.4 & 11.0 & 1.4 & 0.7 \\
\hline Coal, oil, gas and other mining & 325.9 & 0.5 & 0.2 & -0.3 & 1.5 & 0.2 \\
\hline Textiles and apparel & 179.2 & 84.7 & 2.1 & 4.9 & 0.6 & 21.0 \\
\hline Other light manufacturing & 164.1 & 31.3 & 0.4 & 2.9 & -0.1 & 3.6 \\
\hline Paper and mineral products & 97.5 & 9.5 & 0.4 & 6.0 & 0.9 & 1.9 \\
\hline Chemical, rubber and plastic products & 83.0 & 6.2 & 0.4 & 4.3 & 0.7 & 1.5 \\
\hline Iron, steel and metal products & 187.6 & 1.8 & 0.5 & 2.5 & 2.8 & 0.4 \\
\hline Petroleum and coke products & 75.8 & 3.1 & 0.1 & 1.4 & 0.5 & 0.2 \\
\hline Transport equipment & 22.5 & 1.0 & 0.3 & 4.8 & 0.3 & 0.5 \\
\hline Electronics and machinery & 100.8 & 2.8 & 0.4 & 3.1 & 0.4 & 1.4 \\
\hline Other manufacturing & 143.9 & 0.7 & 0.3 & 11.8 & 4.8 & 0.4 \\
\hline Services & -0.1 & -0.2 & 0.3 & 0.3 & -0.5 & -0.4 \\
\hline Total & $\mathbf{6 2 . 5}$ & $\mathbf{1 4 . 7}$ & $\mathbf{0 . 4}$ & $\mathbf{2 . 3}$ & $\mathbf{0 . 5}$ & $\mathbf{2 . 6}$ \\
\hline $\begin{array}{l}\text { Change in trade value } \\
\text { (Million US dollars) }\end{array}$ & $\mathbf{1 5 2 2 0}$ & $\mathbf{5 5 0 2}$ & $\mathbf{8 9 2 4}$ & $\mathbf{6 5 6 3}$ & $\mathbf{6 9 4 5}$ & $\mathbf{5 5 8 4}$ \\
\hline
\end{tabular}

(Source) Authors' simulation results 
Table 7 estimates the percentage changes to be expected in US-India bilateral trade and in total imports and exports when the US and India reduce AVE protection for goods to zero on imports from each other. According to our simulation, US exports to India would increase by 63 percent whereas Indian exports to the US would rise by 15 percent. The expansion of US exports to India tends to be large across all the goods sectors, ranging from 719 percent in processed agriculture to 23 percent in transport sector, reflecting the generally high levels of initial protection in India. Given the relatively low initial US protection, Indian export growth to the US would tend to be much smaller overall. However India would experience a large export expansion in textiles and apparel, about 85 percent, followed by other light manufacturing (31 percent). As these sectors are labor-intensive, the employment effects consequent to the expansion of exports would be disproportionately large. When the US lowered its tariffs against Vietnam's goods from general to Most-Favored Nation (MFN) rates in 2001 (Fukase and Martin 2001), Vietnam's exports of labor-intensive manufacturing such as clothing to the US expanded dramatically, and this led to a disproportionately large job creation effect in Vietnam (Fukase 2013).

Table 8. Trade effects with 50 percent AVE protection cut for services

(\%)

\begin{tabular}{|l|c|c|c|c|c|c|}
\hline & $\begin{array}{c}\text { Exports } \\
\text { from the US } \\
\text { to India }\end{array}$ & $\begin{array}{c}\text { Exports } \\
\text { from India } \\
\text { to the US }\end{array}$ & $\begin{array}{c}\text { Total } \\
\text { US } \\
\text { imports }\end{array}$ & $\begin{array}{c}\text { Total } \\
\text { Indian } \\
\text { Imports }\end{array}$ & $\begin{array}{c}\text { Total } \\
\text { US } \\
\text { Exports }\end{array}$ & $\begin{array}{c}\text { Total } \\
\text { Indian } \\
\text { exports }\end{array}$ \\
\hline Agriculture & -0.2 & 0.0 & 0.0 & 0.0 & -0.1 & 0.1 \\
\hline Processed agriculture & -0.6 & 0.5 & 0.1 & -0.3 & -0.2 & 0.6 \\
\hline Coal, oil, gas and other mining & -0.2 & 0.0 & 0.0 & 0.0 & -0.2 & 0.1 \\
\hline Textiles and apparel & -1.2 & 1.5 & 0.1 & -0.7 & -0.5 & 1.4 \\
\hline Other light manufacturing & -0.8 & 1.1 & 0.1 & -0.4 & -0.4 & 1.0 \\
\hline Paper and mineral products & -0.8 & 0.8 & 0.1 & -0.5 & -0.3 & 0.7 \\
\hline Chemical, rubber and & -0.5 & 0.8 & 0.1 & -0.1 & -0.3 & 0.8 \\
\hline plastic products & -0.5 & 0.9 & 0.0 & 0.0 & -0.4 & 1.0 \\
\hline Iron, steel and metal products & -0.1 & 0.0 & 0.0 & -0.1 & -0.1 & 0.1 \\
\hline Petroleum and coke products & -0.7 & 1.3 & 0.1 & -0.5 & -0.3 & 1.2 \\
\hline Transport equipment & -0.7 & -1 & -0.1 & -0.1 & \\
\hline Electronics and machinery & -1.1 & 2.0 & 0.1 & -0.6 & -0.4 & 1.9 \\
\hline
\end{tabular}




\begin{tabular}{|l|c|c|c|c|c|c|}
\hline & $\begin{array}{c}\text { Exports } \\
\text { from the US } \\
\text { to India }\end{array}$ & $\begin{array}{c}\text { Exports } \\
\text { from India } \\
\text { to the US }\end{array}$ & $\begin{array}{c}\text { Total } \\
\text { US } \\
\text { imports }\end{array}$ & $\begin{array}{c}\text { Total } \\
\text { Indian } \\
\text { Imports }\end{array}$ & $\begin{array}{c}\text { Total } \\
\text { US } \\
\text { Exports }\end{array}$ & $\begin{array}{c}\text { Total } \\
\text { Indian } \\
\text { exports }\end{array}$ \\
\hline Other manufacturing & -1.0 & 1.4 & 0.1 & -0.5 & -0.5 & 1.3 \\
\hline Services & 112.9 & 12.2 & 0.4 & 12.2 & 1.8 & 3.1 \\
\hline Total & $\mathbf{2 7 . 4}$ & $\mathbf{5 . 4}$ & $\mathbf{0 . 1}$ & $\mathbf{1 . 2}$ & $\mathbf{0 . 1}$ & $\mathbf{1 . 5}$ \\
\hline $\begin{array}{l}\text { Change in trade value } \\
\text { (Million US dollars) }\end{array}$ & $\mathbf{6 6 7 0}$ & $\mathbf{2 0 2 5}$ & $\mathbf{2 6 4 3}$ & $\mathbf{3 4 4 5}$ & $\mathbf{1 6 8 0}$ & $\mathbf{3 1 9 6}$ \\
\hline
\end{tabular}

(Source) Authors' simulation results.

Table 8 estimates the trade effects to be expected when the US and India reduce their AVE protection for services by 50 percent. US exports of services to India and those from India to the US are expected to increase by 113 percent and 12 percent, respectively, which would lead to a rise in overall exports from the US to India by 28 percent and from India to the US by 5 percent. Interestingly, the liberalization of services would impact the pattern of trade in goods differently in the US and in India. In the US, the liberalization of services would give rise to a slight contraction in goods exports, with resources reallocated toward now more profitable service sector. In contrast, the rise in exports of services from the US to India would contribute to a rise in India's exports of goods. This is perhaps because imported services provide important inputs for the production of goods, and the increased availability of efficient services may also reduce transaction/transportation costs. Several researchers conclude that service imports may cause developing countries to increase their international competitiveness and facilitate exports (Cebula et al. 2011, Hoekman and Braga 1997). Analyzing US trade data, Cebula et al. (2011) find that service imports from the US have a significant and positive impact on goods exports to the US in the case of low-income countries but not in the case of high-income countries.

Combining liberalization in the trade of goods and services, the results in Table 9 predict that exports from the US to India and those from India to the US may expand by 90 percent and 20 percent respectively. The impacts on total trade for the US are 0.6 percent and 0.7 percent increases in import and export values respectively whereas the corresponding figures are 3.5 percent and 4.1 percent for India. In terms of trade values, the resulting increase in bilateral trade (imports plus exports) is estimated to be $\$ 29$ billion ( 0.21 percent and 2.4 percent of the US's and India's initial GDP respectively). ${ }^{4}$

${ }^{4}$ These estimates are based on the initial trade values in 2007, which is the reference year of GTAP 8. As trade between the US and 
Overall, the total trade of the US and India may increase by 22 billion US dollars, (0.16 percent of initial GDP) and 19 billion US dollars (1.6 percent of initial GDP) respectively.

Table 9. Trade effects with 100 percent AVE protection cut for goods and 50 percent cut for services

$(\%)$

\begin{tabular}{|l|c|c|c|c|c|c|}
\hline & $\begin{array}{c}\text { Exports } \\
\text { from the US } \\
\text { to India }\end{array}$ & $\begin{array}{c}\text { Exports } \\
\text { from India } \\
\text { to the US }\end{array}$ & $\begin{array}{c}\text { Total } \\
\text { US } \\
\text { imports }\end{array}$ & $\begin{array}{c}\text { Total } \\
\text { Indian } \\
\text { Imports }\end{array}$ & $\begin{array}{c}\text { Total } \\
\text { US } \\
\text { Exports }\end{array}$ & $\begin{array}{c}\text { Total } \\
\text { Indian } \\
\text { exports }\end{array}$ \\
\hline Agriculture & 183.0 & 5.3 & 0.5 & 10.2 & 0.8 & 0.2 \\
\hline Processed agriculture & 714.7 & 12.3 & 0.6 & 10.7 & 1.1 & 1.1 \\
\hline Coal, oil, gas and other mining & 325.5 & 0.7 & 0.2 & -0.2 & 1.4 & 0.3 \\
\hline Textiles and apparel & 176.4 & 87.4 & 2.3 & 4.3 & 0.1 & 22.7 \\
\hline Other light manufacturing & 162.2 & 32.8 & 0.6 & 2.6 & -0.5 & 4.6 \\
\hline Paper and mineral products & 96.1 & 10.4 & 0.6 & 5.6 & 0.6 & 2.6 \\
\hline $\begin{array}{l}\text { Chemical, rubber and } \\
\text { plastic products }\end{array}$ & 82.4 & 7.1 & 0.5 & 4.2 & 0.4 & 2.3 \\
\hline Iron, steel and metal products & 186.3 & 2.7 & 0.6 & 2.5 & 2.4 & 1.3 \\
\hline Petroleum and coke products & 75.7 & 3.2 & 0.1 & 1.4 & 0.5 & 0.3 \\
\hline Transport equipment & 21.7 & 2.3 & 0.4 & 4.4 & 0.0 & 1.7 \\
\hline Electronics and machinery & 98.8 & 4.8 & 0.6 & 2.6 & -0.1 & 3.2 \\
\hline Other manufacturing & 141.9 & 2.1 & 0.5 & 11.3 & 4.2 & 1.6 \\
\hline Services & 112.9 & 12.0 & 0.7 & 12.6 & 1.6 & 3.1 \\
\hline Total & $\mathbf{8 9 . 6}$ & $\mathbf{2 0 . 3}$ & $\mathbf{0 . 6}$ & $\mathbf{3 . 5}$ & $\mathbf{0 . 7}$ & $\mathbf{4 . 1}$ \\
\hline $\begin{array}{l}\text { Change in trade value } \\
\text { (Million US dollars) }\end{array}$ & $\mathbf{2 1 8 2 9}$ & $\mathbf{7 6 0 6}$ & $\mathbf{1 2 6 1 4}$ & $\mathbf{1 0 1 8 0}$ & $\mathbf{9 2 5 8}$ & $\mathbf{8 9 2 5}$ \\
\hline
\end{tabular}

(Source) Authors' simulation results. 
Table 10. Trade effects with 100 percent cut for goods and 50 percent cut for services plus India's MFN liberalization

$(\%)$

\begin{tabular}{|l|c|c|c|c|c|c|}
\hline & $\begin{array}{c}\text { Exports } \\
\text { from the US } \\
\text { to India }\end{array}$ & $\begin{array}{c}\text { Exports } \\
\text { from India } \\
\text { to the US }\end{array}$ & $\begin{array}{c}\text { Total } \\
\text { US } \\
\text { imports }\end{array}$ & $\begin{array}{c}\text { Total } \\
\text { Indian } \\
\text { Imports }\end{array}$ & $\begin{array}{c}\text { Total } \\
\text { US } \\
\text { Exports }\end{array}$ & $\begin{array}{c}\text { Total } \\
\text { Indian } \\
\text { exports }\end{array}$ \\
\hline Agriculture & 13.7 & 31.3 & -0.1 & 80.0 & 0.7 & 24.3 \\
\hline Processed agriculture & 36.9 & 37.6 & -0.1 & 233.2 & 0.5 & 23.8 \\
\hline Coal, oil, gas and other mining & 41.3 & 43.3 & -0.3 & 12.1 & 0.2 & 48.5 \\
\hline Textiles and apparel & 43.6 & 134.4 & 2.3 & 50.0 & -0.3 & 55.0 \\
\hline Other light manufacturing & 44.1 & 67.2 & -0.2 & 32.2 & 0.5 & 33.1 \\
\hline Paper and mineral products & 25.8 & 27.6 & 0.0 & 26.0 & 0.5 & 19.2 \\
\hline $\begin{array}{l}\text { Chemical, rubber and } \\
\text { plastic products }\end{array}$ & 2.3 & 44.0 & 0.0 & 21.9 & 0.0 & 37.1 \\
\hline Iron, steel and metal products & 35.5 & 33.2 & 0.0 & 28.6 & 0.7 & 32.4 \\
\hline Petroleum and coke products & 14.4 & 32.6 & 0.0 & 9.6 & -0.8 & 26.4 \\
\hline Transport equipment & -21.4 & 25.4 & -0.2 & 14.1 & -0.5 & 25.0 \\
\hline Electronics and machinery & 12.0 & 48.3 & -0.2 & 15.1 & 0.5 & 46.9 \\
\hline Other manufacturing & 41.3 & 29.2 & 0.2 & 40.3 & 0.9 & 28.0 \\
\hline Services & 45.7 & 19.7 & 0.2 & 45.3 & 0.8 & 10.5 \\
\hline Total & $\mathbf{1 2 . 5}$ & $\mathbf{4 4 . 9}$ & $\mathbf{0 . 0}$ & $\mathbf{2 5 . 8}$ & $\mathbf{0 . 3}$ & $\mathbf{2 9 . 1}$ \\
\hline $\begin{array}{l}\text { Change in trade value } \\
\text { (Million US dollars) }\end{array}$ & $\mathbf{3 0 4 3}$ & $\mathbf{1 6 8 3 4}$ & $\mathbf{7 0 0}$ & $\mathbf{7 4 7 5 2}$ & $\mathbf{3 8 8 0}$ & $\mathbf{6 2 8 3 7}$ \\
\hline
\end{tabular}

(Source) Authors' simulation results.

Table 10 presents the results of a scenario in which India first signs a FTA with the US and then liberalizes with all its other trading partners on an MFN basis. Using an India-US FTA for further liberalization may be particularly suitable for India relative to using mechanisms under the World Trade Organization (WTO). This is because India is not required to lower its tariff rates under the WTO as India's bound tariff rates are far higher than its applied rates; and an India-US FTA is likely to become a comprehensive, deep and symmetrical agreement while India has little obligation to reduce its protection 
at the WTO because of the special and differential treatment principle (Lawrence and Chadha 2004). The simulation results show that total Indian imports and exports would expand substantially by 26 percent, and 29 percent respectively, and India's exports to the US would increase disproportionately relative to other countries (45 percent) since India would continue to receive preferential market access in the US market. The rise in India's imports is projected to be especially large in the processed agricultural sector (233 percent), whereas India's exports would tend to expand across sectors, because of the real exchange rate depreciation associated with reduction in trade barriers (Salter 1959). In value terms, India's trade expansion would be about seven times larger relative to the base scenario, with India's total trade expanding by 138 billion US dollars (11 percent of initial GDP).

\section{Table 11. Output effects}

(Percent change in output)

\begin{tabular}{|c|c|c|c|c|c|c|c|c|}
\hline & \multicolumn{2}{|c|}{$\begin{array}{c}\text { Goods } \\
\text { Liberalization }\end{array}$} & \multicolumn{2}{|c|}{$\begin{array}{c}\text { Services } \\
\text { Liberalization }\end{array}$} & \multicolumn{2}{|c|}{$\begin{array}{c}\text { Goods }+ \\
\text { Services } \\
\text { Liberalization } \\
\end{array}$} & \multicolumn{2}{|c|}{$\begin{array}{c}\text { Goods + } \\
\text { Services + } \\
\text { India MFN } \\
\end{array}$} \\
\hline & US & India & US & India & US & India & US & India \\
\hline Agriculture & 0.10 & -0.06 & -0.05 & 0.05 & 0.05 & -0.01 & 0.15 & -1.99 \\
\hline Processed agriculture & 0.05 & -0.31 & -0.02 & 0.07 & 0.04 & -0.24 & 0.03 & -8.89 \\
\hline Coal, oil, gas and other mining & -0.05 & -0.16 & -0.04 & 0.13 & -0.09 & -0.04 & -0.03 & -1.91 \\
\hline Textiles and apparel & -0.92 & 7.05 & -0.18 & 0.68 & -1.10 & 7.83 & -1.28 & 19.07 \\
\hline Other light manufacturing & -0.13 & 0.74 & -0.07 & 0.47 & -0.20 & 1.20 & 0.03 & 7.89 \\
\hline Paper and mineral products & 0.02 & -0.49 & -0.06 & 0.07 & -0.04 & -0.42 & 0.04 & -1.12 \\
\hline Chemical, rubber and plastic products & 0.05 & -0.47 & -0.18 & 0.4 & -0.12 & -0.07 & -0.05 & 4.31 \\
\hline Iron, steel and metal products & 0.29 & -1.17 & -0.21 & 0.53 & 0.08 & -0.65 & 0.08 & -1.54 \\
\hline Petroleum and coke products & 0.09 & -0.21 & 0.01 & 0.08 & 0.09 & -0.13 & -0.13 & 6.51 \\
\hline Transport equipment & 0.00 & -1.55 & -0.14 & 0.47 & -0.13 & -1.09 & -0.14 & -0.44 \\
\hline Electronics and machinery & -0.07 & -1.01 & -0.24 & 0.72 & -0.3 & -0.3 & 0.12 & 2.13 \\
\hline Other manufacturing & 0.81 & -0.88 & -0.23 & 0.65 & 0.58 & -0.25 & -0.16 & 8.71 \\
\hline Services & 0.00 & 0.02 & 0.03 & -0.13 & 0.03 & -0.11 & 0.00 & 0.06 \\
\hline
\end{tabular}

(Source) Authors' simulation results.

Table 11 reports the output effects resulting from the simulation experiments reported in Table 7 through 10 . Columns 1 and 2 of Table 11 reveal that the impacts of goods 
liberalization on output would be most pronounced in textiles and apparel: the output of this sector in India increases by 7 percent, that in the US contracts by 0.9 percent. It appears that, resulting from goods liberalization, productive resources are allocated more efficiently and India is able to allocate additional resources to sectors in which it has a comparative advantage.

Consequent to service trade liberalization (columns 3 and 4), the output of services would contract slightly in India due to increased competition from the US. However, the increased efficiency of the services sectors would contribute to an expansion of output across all goods sectors. This result is broadly consistent with the view that opening the services sector to foreign providers is a channel through which the liberalization in the trade of services contributes to improved performance of downstream manufacturing sectors (Arnold et al. 2016 for India, Arnold, Javorcik and Mattoo 2011 for Czech Republic). For instance, examining the link between policy reforms in services and the production of manufacturing firms from 1993 to 2005, Arnold et al. (2016) show that India's reforms in services, which include banking, telecommunications, insurance and transport reforms, had positive effects on the productivity of manufacturing.

Combining the liberalization of goods and services (columns 5 and 6), the performance of the Indian goods sector tends to be slightly better relative to the liberalization of the goods market alone. For instance, the growth of the output of textiles and apparel increases from 7.1 percent to 7.8 percent. The strategy of extending its liberalization of goods and services trade to all its suppliers (the last two columns of Table 11), would accelerate resource reallocation across sectors in India. Relative to the baseline scenario, the expansion of the textiles and apparel sector more than doubles; other sectors such as light manufacturing, chemical, rubber and plastic products, petroleum and coke products also expand sizably; but the contractions of some sectors, for instance, that of processed agriculture, are more pronounced. An India-US FTA is also likely to promote resource reallocation in the US, but its impact on the structure of US production appears to be generally small.

\section{Welfare effects}

In order to analyze the impacts of FTAs on economic welfare, we decompose the Equivalent Variation (EV) into allocative efficiency and TOT components, following Huff and Hertel (2000). The allocative efficiency effects are further decomposed into 
trade creation, trade diversion effects and other allocative efficiency components. ${ }^{5}$

Table 12. Welfare effects of potential FTA between India and the US

(Million US dollars)

\begin{tabular}{|c|c|c|c|c|c|c|c|c|c|c|c|c|}
\hline & \multicolumn{2}{|c|}{$\begin{array}{c}\text { Goods } \\
\text { Liberalization }\end{array}$} & \multicolumn{2}{|c|}{$\begin{array}{c}\text { Services } \\
\text { Liberalization }\end{array}$} & \multicolumn{2}{|c|}{$\begin{array}{c}\text { Goods + } \\
\text { Services } \\
\text { Liberalization }\end{array}$} & \multicolumn{2}{|c|}{$\begin{array}{c}\text { Goods }+ \\
\text { Services }+ \\
\text { India MFN }\end{array}$} & \multicolumn{2}{|c|}{$\begin{array}{c}\text { Only } \\
\text { the US } \\
\text { removes } \\
\text { protection } \\
\end{array}$} & \multicolumn{2}{|c|}{$\begin{array}{c}\text { Only India } \\
\text { removes } \\
\text { protection }\end{array}$} \\
\hline & US & India & US & India & US & India & US & India & US & India & US & India \\
\hline 1. Allocative efficiency effect & 289 & 234 & 257 & 1550 & 536 & 1804 & -171 & 26205 & -74 & 738 & 642 & 1097 \\
\hline 1.1 Net TC vs. TD & 80 & -462 & 176 & 1340 & 176 & 898 & -221 & 16361 & \begin{tabular}{|l|l}
-71 & \\
\end{tabular} & & & 310 \\
\hline Trade Creation (TC) & 207 & 939 & 292 & 3292 & 292 & 4241 & 482 & & 247 & & & 4144 \\
\hline Trade Diversion (TD) & -127 & -1401 & -116 & -1952 & -116 & -3343 & -704 & & -319 & & & -3834 \\
\hline $\begin{array}{l}\text { 1.2 Other allocative } \\
\text { efficiency effect }\end{array}$ & 210 & 696 & 80 & 210 & 360 & 906 & 50 & 9844 & -2 & $\begin{array}{l}738 \\
\end{array}$ & 642 & 786 \\
\hline 2. Terms of Trade (TOT) Effects & 2033 & 9 & 1104 & -400 & 3133 & -392 & 642 & -12692 & -477 & 1227 & 3551 & -1647 \\
\hline Total EV Change & 2322 & 243 & 1360 & 1150 & 3669 & 1412 & 471 & 13513 & $\mid-551$ & 1965 & 4193 & -550 \\
\hline
\end{tabular}

(Source) Authors' simulation results.

The first eight columns of Table 12 report the results of our welfare decomposition using the same scenarios described above. The economic impacts from goods trade liberalization would be positive for both the US and India as they are projected to experience welfare gains of 2.3 billion US dollars and 0.2 billion US dollars, respectively (column 1 2). The gains coming from the TOT component are especially large for the US (2.0 billion US dollars), mainly reflecting initially high protection in India. India would suffer from some trade diversion in goods trade liberalization ${ }^{6}$ although, in general, improved allocative efficiency may outweigh this loss. The corresponding figures resulting from services liberalization for the US and India are 1.4 billion US

\footnotetext{
${ }^{5}$ The GTAP model incorporates many pre-existing distortions in the forms of taxes and subsidies (Huff and Hertel 2000). The welfare changes in the model are attributed to the interactions between taxes (or subsidies) and equilibrium quantity changes taking place over the course of simulations. Among allocative efficiency effects, this paper focuses on quantifying trade creation and trade diversion type effects, which are illustrated in Figure 7 and Figure 8. These effects are measured as the summation of the tariff revenue weighted by imports quantity changes, i.e., by aggregating the changes in tariff revenues within FTA (trade creation) and outside of the FTA (trade diversion) (Hertel et al. 2007). The welfare effect resulting from changes in the relative prices of savings and investment is not included in our welfare decomposition.

${ }^{6}$ This result is partly attributable to the fact that India's initial AVE protection of 9.9 percent against the U.S goods (Table 4) is lower than the rates India applies to its other trading partners. Thus, consequent to the discriminatory trade liberalization, India would expect a large tariff revenue loss from the other partners.
} 
dollars and 1.2 billion US dollars (Columns 3 4).

The combination of goods and services trade liberalization (baseline scenario), would result in the US and India gaining by 3.7 billion US dollars and 1.4 billion US dollars, respectively (about 0.03 percent and 0.1 percent of initial US GDP and initial Indian GDP, respectively) (Columns 5 and 6). When India extends the removal of barriers on an MFN basis (Columns 7 and 8), India's welfare would expand dramatically to 13.5 billion US dollars (about 1.0 percent of its initial GDP) as its much larger allocative efficiency gains far surpass its deteriorating TOT effects. The strategy of lowering external barriers in the aftermath of an FTA is documented both in ASEAN (Calvo-Pardo, Freund, and Ornelas 2011) and in Latin America (Estevadeordal, Freund and Ornelas 2008). For instance, Estevadeordal et al. (2008) found strong evidence of regional agreements having induced a faster decline in external tariffs in Latin America and conclude that free trade areas are likely to be building blocks in the region. While Limao (2006) concludes that PTAs reduce the ambition of subsequent multilateral liberalization, Estevadeordal, Freund and Ornelas (2008) indicated that this result applies only to the US and the EU, rather than to developing countries where liberalization can have much greater welfare impacts.

Experiments in the last four columns of Table 12 separate the baseline scenario into two parts, i.e., the effects from the US lowering its protection against India's exports (Columns 9 and 10) and from India's doing so against US exports (Columns 11 and 12). The results reveal that both countries would lose if they only lowered their own barriers without obtaining reciprocal commitments, as gains resulting from doing so appear to be reaped by their partners. Our finding suggests that FTA models which focus only on the import side are misleading, and highlights the importance of negotiating concessions by FTA partner countries.

\section{B. India-US FTA in the presence of other FTAs}

The series of simulations in Section IV.A assumes that both countries negotiate only an India-US FTA. However, as the US and India have already begun negotiating other FTAs, there arises the important question of how the welfare and trade impacts of an India-US FTA would be affected by prior decisions to proceed with other agreements. To answer this question, we first consider the impacts of several regional agreements that are under negotiation. Then, we will examine what would happen if the US and/or India 
were to add an India-US FTA after the completion of any or all of the other agreements.

\section{Welfare effects}

Panel A of Table 13 considers the welfare consequences of alternative FTAs, namely under the TPP ${ }^{7}$ (scenario A1W) and the US-EU FTA (scenario A2W) for the US as well as an India-EU FTA (scenario A3W) and an India-ASEAN FTA (scenario A4W). For the sake of transparency and for the purpose of comparing the results of alternative FTAs with an India-US FTA, which does not yet exist, we apply the same assumption that was applied to the preceding simulations, i.e., 100 percent AVE tariff cuts for trade in goods and 50 percent cuts for trade in services each other.

At the time of writing (2013), the eleven official TPP members were: Australia, Brunei Darussalam, Canada, Chile, Malaysia, Mexico, New Zealand, Peru, Singapore, the US, and Vietnam. 


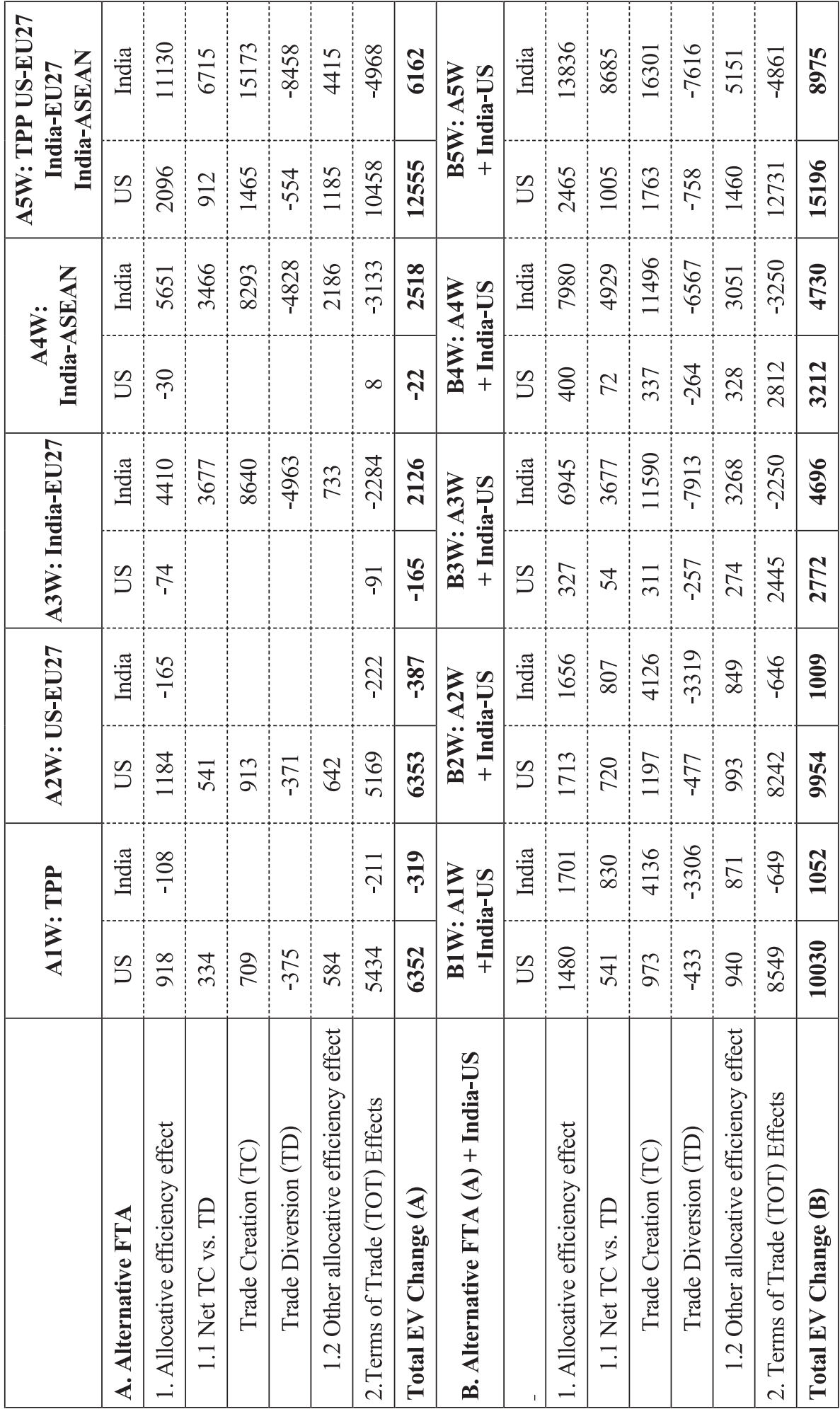




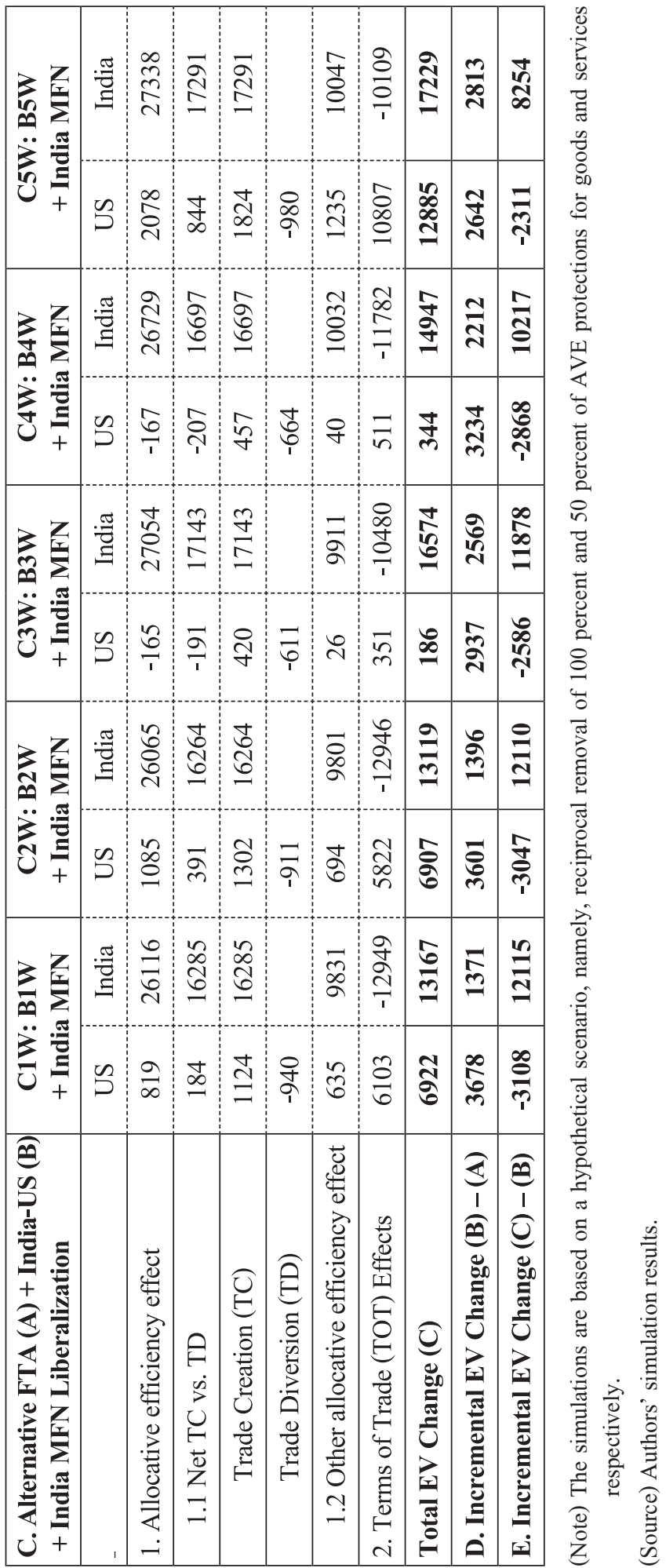


The results suggest that the US would gain roughly equally from the TPP and US-EU FTA (6.4 US billion dollars) and that the welfare gains from each of these agreements appear to be larger than those resulting from a potential India-US FTA (3.7 billion US dollars). Turning to alternative FTA partners for India, the welfare gains for India from an India-EU FTA and an India-ASEAN FTA are estimated to be 2.1 billion US dollars and 2.5 billion US dollars respectively. These gains are also larger than the gains likely to result from a potential India-US FTA presented in Table 12 (1.4 billion US dollars). ${ }^{8}$ Scenarios A1W A4W of Panel A in Table 13 show that the countries that are excluded from FTAs tend to lose because they are discriminated against in FTA members' markets. These losses are predicted to be particularly large for India when the US concludes an FTA with Europe (loss of 387 million US dollar per year) and India's exports to both these major markets face greater competition from suppliers within these trading blocs.

The last two columns show what happens if we combine all these FTAs, namely, the TPP, US-EU, India-EU and India-ASEAN (scenario A5W). The results show that both the US and India gain much more than under any individual FTA (12.6 billion US dollars for the US and 6.2 billion US dollars for India).

Panel B of Table 13 reports the total welfare changes resulting from adding an IndiaUS FTA involving both goods and services to each alternative FTA evaluated in Panel $\mathrm{A}$ (scenarios B1W B5W). The results show that the total welfare would rise by adding an India-US FTA to prior agreements in each case. Panel D of Table 13 shows the incremental benefits resulting from adding an India-US FTA, which are the differences between welfare gains reflected in Panels A and B. Comparing the welfare changes in Panel D with those in the baseline scenario (Columns 5 6 in table 12), the benefits to India are predicted to increase if it undertakes prior agreements. With an India-EU agreement in place, for example, the gains from an India-US agreement rise from 1.4 billion US dollars (baseline scenario) to 2.6 billion US dollars for India (scenario B3W). Similarly, given an India-ASEAN agreement, the incremental gains from an India-US FTA rise to 2.2 billion US dollars (scenario B4W). ${ }^{9}$ With all of the other agreements in place, the incremental gains from an India-US agreement rise to 2.8 billion US dollars.

\footnotetext{
${ }^{8}$ However, the results need to be interpreted in the context of our assumptions. These are estimates of the potential and do not take into account leakages from measures such as sensitive products that might later be excluded from liberalization. For instance, in the ASEANIndia FTA, India has excluded a number of agricultural products from liberalization, putting them in the Exclusion List (Hoda and Gulati 2014).

${ }^{9}$ This is mainly because, with an India-ASEAN agreement in place, India would have reduced its initially high barriers against the ASEAN market (23.3 percent) (Table 4). Thus, the loss from trade diversion by adding an India-US FTA would be smaller.
} 
Panel $\mathrm{C}$ in Table 13 reports the total welfare effects when India liberalizes on an MFN basis, a discussion that is conditional on one or more prior agreements including an India-US FTA (scenarios $\mathrm{C} 1 \mathrm{~W} \sim \mathrm{C} 5 \mathrm{~W}$ ). The results show that the benefits for India tend to rise substantially relative to the corresponding scenarios explored in this paper (17 billion US dollars). ${ }^{10}$ For the US, the incremental welfare change resulting from India's MFN liberalization is negative (Panel E), as it loses from the erosion of its preferential access to the Indian market.

\footnotetext{
${ }^{10}$ It is noted that the incremental benefit from unilateral liberalization tends to be smaller relative to the corresponding scenario without prior agreements. For instance, under scenario C5W, the incremental gain coming from unilateral liberalization of 8 billion US dollars (Panel E) is smaller than the corresponding scenario without prior agreements of 12 billion US dollars (the difference between column 6 and column 8 in table 12). The smaller net gain from unilateral liberalization conditional on more prior FTAs is not surprising, since the scope of the liberalization becomes smaller when India has already removed its protection against more FTA partners.
} 


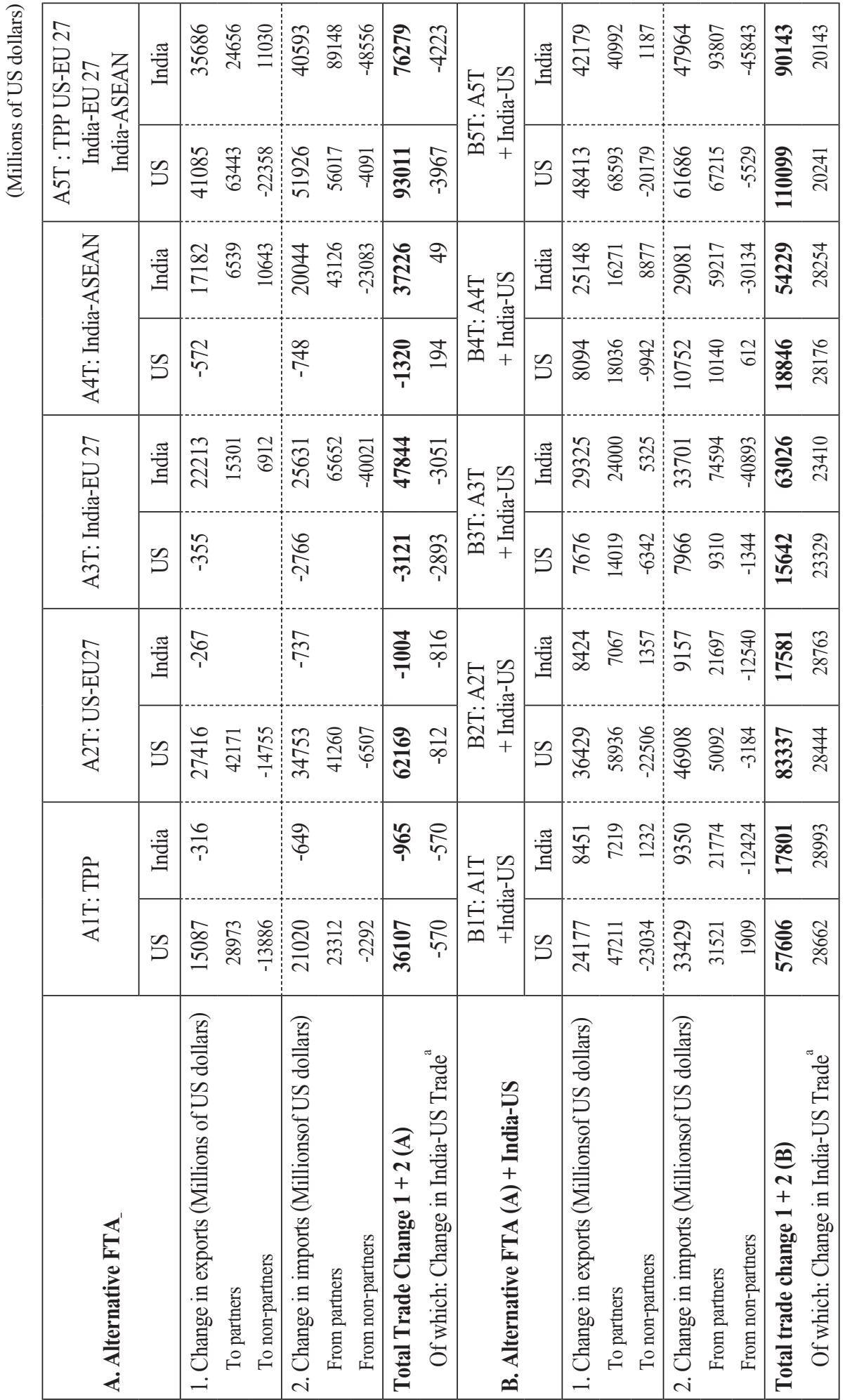




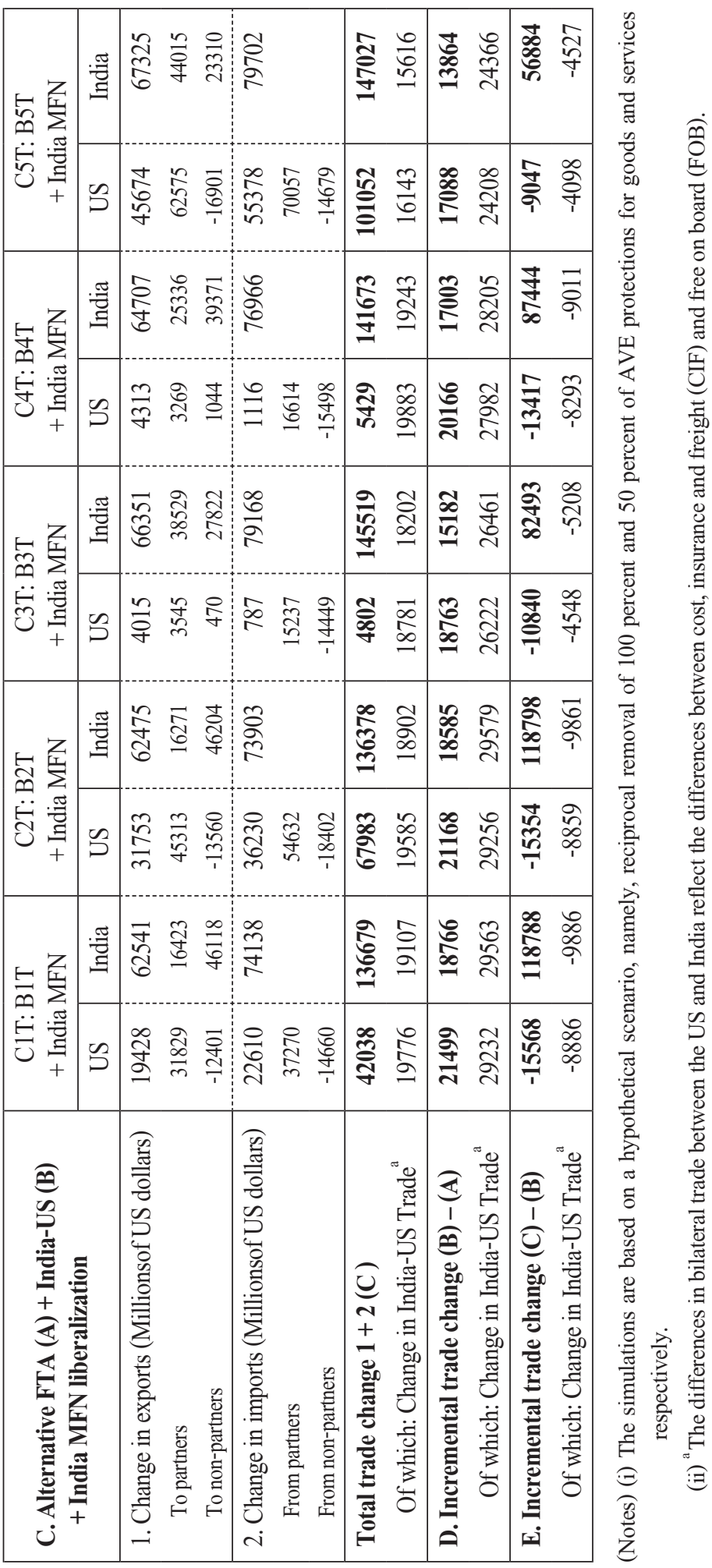




\section{Trade effects}

Table 14 repeats the same experiments, but reports the trade effects (evaluated by the changes in import plus export values) instead of the welfare measures.

Panel A shows that the US and India would experience a rise in trade by concluding an FTA, while the excluded country would tend to lose trade (scenarios A1T A4T). For instance, following the conclusion of the TPP (scenario A1T) and an US-EU FTA (scenario A2T), the US trade would increase by 36 billion US dollars and by 62 billion US dollars respectively. If the trade effects from the TPP and a US-EU FTA are combined (scenarios A1T $+\mathrm{A} 2 \mathrm{~T}$ ), the change in total trade for the US would rise to 98 billion US dollars. ${ }^{11}$ However, these agreements would lead Indian trade to decrease by about 1 billion US dollars in scenarios A1T and A2T and by 2 billion US dollars in the combined scenario of A1T and A2T. Panel A of Table 14 also shows that the trade effect resulting from concluding an alternative FTA on Indian-US bilateral trade would tend to be negative except in scenario A4T.

Panel B and Panel D in Table 14 confirm that adding an India-US FTA conditional on prior FTA agreements would create trade for both countries (scenarios B1T B5T). For instance, by concluding an India-US FTA in addition to the TPP (scenario B1T) or an US-EU FTA (scenario B2T), the total US trade may increase by 58 billion US dollars and 83 billion US dollars respectively. If TPP, a US-EU FTA and an India-US FTA are combined (scenarios B1T + B2T), the change in total trade for the US would rise to 119 billion US dollars (not reported in Table 14). For India, concluding an FTA with the US may lead to an increase in its total trade by 18 billion US dollars in scenarios B1T and B2T and by 17 billion US dollars in the combined scenario of B1T and B2T. In terms of the impacts of these scenarios on trade between India and the US, the estimated increase in bilateral trade ranges from 20 billion US dollars in scenario B5T to 29 billion US dollars in scenario B1T.

With India extending its concessions on an MFN basis (Panel C), India's trade would expand considerably while the US's trade would decrease subsequent to the loss of the preference (scenarios $\mathrm{C} 1 \mathrm{~T} \sim \mathrm{C} 5 \mathrm{~T}$ ). As a result, the largest trade effects would be found in the combination of scenario B1T and B2T for the US (119 billion US dollars) and in scenario C5T for India (147 billion US dollars).

\footnotetext{
${ }^{11}$ The result of the combined scenario is not reported in order to conserve space.
} 


\section{Conclusions}

This paper explored the economic implications of a potential FTA between India and the US using an applied general equilibrium model. Since the nature of the liberalization to be adopted is unknown at this stage, the potential impacts of an FTA are evaluated under a hypothetical scenario, namely 100 percent and 50 percent AVE tariff cuts for goods and services respectively. The results suggest that the overall impacts of an India-US FTA would increase real incomes in both for the US and India. While gains from trade creation would tend to be offset by trade diversion on the import side, both countries would gain from improved access to each other's markets on the export side. The US would gain largely through terms of trade improvement for its goods and services as the initial protection in India is particularly high. India would experience an expansion of exports and of output especially in the textiles and apparel sectors. Moreover, the availability of more efficient services imported from the US appears to have favorable impacts on production and exports of goods in India.

As the US and India are negotiating other FTAs such as the US-EU agreement, the TPP, and India's agreement with the ASEAN, the paper explored how the economic implications of an India-US FTA would vary depending on the existence of different prior FTAs. The results reveal that adding an India-US FTA to prior agreements tends to bring additional welfare benefits to both countries. In particular, India would be likely to gain substantially if it were to conclude an FTA with the US and other trading partners and then to extend its commitment to all of its trading partners on an MFN basis. This is because MFN liberalization unwinds costly trade diversion and promotes a more efficient resource allocation towards sectors in which India has a comparative advantage. Finally, since countries excluded from FTAs tend to lose with their being discriminated against in FTA parties' markets and with their trade being diverted in favor of FTA members, both the US and India appear to have an incentive to enlarge the scopes of their FTAs. All the above findings suggest that an India-US FTA may potentially become a building block towards more liberal trade regimes for both countries.

Finally, our simulation exercises are subject to a number of limitations and leave many issues for future research. First, it is well known that trade-weighted averages of tariff rates tend to underestimate the impact of protection and that this in turn is likely to result in the underestimate of welfare changes. In order to overcome this problem, more refined aggregators of trade distortions of the type used by Laborde et al. (2016) would 
be needed. Second, while our results suggest both countries would gain in aggregate from an FTA, we do not address explicitly how the trade reforms would influence poverty. The consequences of trade liberalization on poverty are complex and appear to be mixed depending on country, model, nature of trade liberalization and the channels through which trade reforms would influence poverty. ${ }^{12}$ For India, there exist studies which suggest potentially adverse impacts of trade reforms on poverty (Anderson, Cockburn and Martin 2010, Topalova 2010). For instance, examining the 1991 Indian trade liberalization episode, Topalova (2010) found that rural districts, in which production sectors more exposed to import liberalization were concentrated, experienced slower reduction in poverty in India. In contrast, Hasan, Mitra and Ural (2007) found that trade liberalization is positively associated with poverty reduction, at least in states with flexible labor-market institutions.

One channel through which an India-US FTA would influence poverty in India is through positive impacts on wages for unskilled workers, as India is a labor-abundant country and the FTA would increase the demand for labor-intensive exports. Our simulation results suggest that real wages for unskilled workers would increase by 0.4 percent following an India-US FTA. In the presence of other FTAs, real wage rates for unskilled workers would rise by 0.8 percent with the implementation of an IndiaUS FTA (scenario B5W) and by a further 2.7 percent if India liberalized unilaterally in addition to an India-US FTA and other FTAs (scenario C5W). Further studies, perhaps using microsimulation models of the type used by Kyophilavong, Record, Takamatsu, Nghardsaysone and Sayvaya (2016) would be a useful extension of our analysis.

Received 23 May 2016, Revised 24 July 2016, Accepted 26 October 2016

\section{References}

Anderson, Kym, John Cockburn, and Will Martin, eds. Agricultural Price Distortions, Inequality, and Poverty, Washington, DC: World Bank (2010).

Arnold, Jens M., Beata S. Javorcik, Molly Lipscomb, and Aaditya Mattoo. "Services

\footnotetext{
${ }^{12}$ See Winters, McCulloch and McKay (2004) for a review.
} 
Reform and Manufacturing Performance: Evidence from India." The Economic Journal 126(590) (2016): 1-39.

Arnold, Jens M., Beata S. Javorcik, and Aaditya Mattoo. "Does Services Liberalization Benefit Manufacturing Firms?: Evidence from the Czech Republic." Journal of International Economics 85 (2011): 136-146.

Bergsten, C. Fred. "India's Rise: a Strategy for Trade-led Growth." Peterson Institute for International Economics (PIIE) Briefing 15-4 (2015). Available online at https://piie. com/publications/briefings/piieb15-4.pdf. Accessed July 14, 2016.

Borchert, Ingo, Batshur Gootiiz, and Aaditya Mattoo. "Policy Barriers to International Trade in Services: Evidence from a New Database." The World Bank Economic Review 28(1) (2014): 162-188.

Calvo Pardo, Hector, Caroline L. Freund, and Emanuel Ornelas. "The ASEAN Free Trade Agreement: Impact on Trade Flows and External Trade Barriers." In Costs and Benefits of Regional Economic Integration in Asia, edited by Robert Barro and JongWha Lee. Oxford: Oxford University Press (2011).

Cebula, Richard J., Joy Mazumdar, and Usha Nair-Reichert. "US Trade and Access to Trade Facilitating Services in Partner Countries: An Empirical Analysis." Journal of Economic Integration 26(3) (2011): 411-432.

Chadha, Rajesh, Drusilla K. Brown, Alan V. Deardorff, and Robert M. Stern. "Computational Analysis of the Impact on India of the Uruguay Round and the Forthcoming WTO Trade Negotiations." Ann Arbor: University of Michigan (2000).

Estevadeordal, Antoni, Caroline Freund, and Emanuel Ornelas. "Does Regionalism Affect Trade Liberalization toward Nonmembers?" The Quarterly Journal of Economics 123(4) (2008): 1531-1575.

Fukase, Emiko. "Export Liberalization, Job Creation, and the Skill Premium: Evidence from the US-Vietnam Bilateral Trade Agreement (BTA)." World Development 41 (2013): 317-337.

Fukase, Emiko, and Will Martin. "Economic Implications of a Potential Free Trade Agreement between India and the United States." World Bank Policy Research Working Paper 7212 (2015). 
Fukase, Emiko, and Will Martin. "A Quantitative Evaluation of Vietnam's Accession to the ASEAN Free Trade Area." Journal of Economic Integration 16(4) (2001): 545-567.

Fukase, Emiko, and L. Alan Winters. "Possible Dynamic Effects of AFTA for the New Member Countries." The World Economy 26(6) (2003): 853-871.

Fukui, E. Tani, and Christine A. McDaniel. "Services Liberalization and Computable General Equilibrium Modeling: Beyond Tariff Equivalents." Journal of International Commerce and Economics. Washington, DC: United States International Trade Commission (2010).

Gervais, Antoine, and J. Bradford Jensen. "Are Services Tradable? Evidence from US Microdata." NBER Working Paper 19759 (2013).

Guimbard, Houssein, Sébastien Jean, Mondher Mimouni, and Xavier Pichot. "MAcMapHS6 2007, an Exhaustive and Consistent Measure of Applied Protection in 2007." International Economics 130 (2012): 99-121.

Hasan, Rana, Devashish Mitra, and Beyza P. Ural. "Trade Liberalization, Labor-market Institutions and Poverty Reduction: Evidence from Indian States." In India Policy Forum 3(1): 71-122. National Council of Applied Economic Research (2007).

Hoda, Anwarul and Ashok Gulati. "Towards an India-US FTA in Agriculture." Mimeo (2014).

Hoekman, Bernard, and Carlos A. Primo Braga. "Protection and Trade in Services: a Survey." Open Economies Review 8(3) (1997): 285-308.

Hertel, Thomas W. Global Trade Analysis: Modeling and Applications, New York: Cambridge University Press (1996).

Hertel, Thomas, David Hummels, Maros Ivanic, and Roman Keeney. "How Confident Can We be of CGE-based Assessments of Free Trade Agreements?" Economic Modelling 24(4) (2007): 611-635.

Hufbauer, Gary Clyde, Jeffrey J. Schott, and Woan Foong Wong. Figuring Out the Doha Round 91. Washington, DC: Peterson Institute for International Economics (2010).

Huff, Karen, and Thomas Hertel. "Decomposing Welfare Changes in the GTAP model." GTAP Technical Paper 5 (2000).

International Monetary Fund (IMF). World Economic Outlook: Update. Washington, 
DC: International Monetary Fund (2016).

Jafari, Yaghoob, and David G. Tarr. "Estimates of Ad Valorem Equivalents of Barriers against Foreign Suppliers of Services in Eleven Services Sectors and 103 Countries." World Bank Policy Research Working Paper 7096 (2014).

Konan, Denise Eby, and Keith E. Maskus. "Quantifying the Impact of Services Liberalization in a Developing Country." Journal of Development Economics 81(1) (2006): 142-162.

Kyophilavong, Phouphet, Richard Record, Shinya Takamatsu, Konesawang Nghardsaysone, and Inpaeng Sayvaya. "Effects of AFTA on Poverty: Evidence from Laos." Journal of Economic Integration 31(2) (2016): 353-376.

Laborde, David, Will Martin, and Dominique Van der Mensbrugghe. "Measuring the Benefits of Global Trade Reform with Optimal Aggregators of Distortions." Review of International Economics, Published online 3 November (2016) DOI: 10.1111/roie.12271

Lawrence, Robert Z., and Rajesh Chadha. "Should a US-India FTA Be Part of India's Trade Strategy?" In India Policy Forum 2004, edited by Bery S., Bosworth, B. and Panagariya, Arvind, 69-134: Brookings Institution Press (2004).

Limão, Nuno. "Preferential Trade Agreements as Stumbling Blocks for Multilateral Trade Liberalization: Evidence for the United States." The American Economic Review 96(3) (2006): 896-914.

Petri, Peter A., Michael G. Plummer, and Fan Zhai. "The Trans-Pacific Partnership and Asia-Pacific Integration: A Quantitative Assessment." In Policy Analyses in International Economics 98. Peterson Institute for International Economics and East-West Center (2012).

Robinson, Sherman, Zhi Wang, and Will Martin. "Capturing the Implications of Services Trade Liberalization." Economic Systems Research 14(1) (2002): 3-33.

Salter, Wilfred EG. "Internal and External Balance: The Role of Price And Expenditure Effects." Economic Record 35(71) (1959): 226-238.

Topalova, Petia. "Factor Immobility and Regional Impacts of Trade Liberalization: Evidence on Poverty from India." American Economic Journal: Applied Economics 2(4) (2010): 1-41. 
Winters, L. Alan, Neil McCulloch, and Andrew McKay. "Trade Liberalization and Poverty: the Evidence So Far." Journal of economic literature 42(1) (2004): 72-115. 